\title{
Characterization of seventeenth century papers from Valvasor's collection of the Zagreb Archdiocese
}

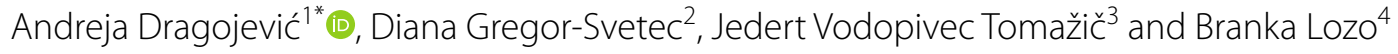

\begin{abstract}
Valvasor's library is a unique example of a Seventeenth century personal library, including over 7300 prints and 1530 books. Today, it is kept in the Metropolitan Library of the Zagreb Archdiocese which is part of the Croatian State Archives. In this study, we analysed a selection of papers from Valvasor's collection (VC) of unknown origin and composition. We used a dual approach, combining the results of the analyses of two sets of samples to find the most useful tools for the characterization of historical handmade papers. 144 randomly selected papers were included in the study. As the VC is a cultural heritage, only non-destructive analyses were used, such as visual inspection, surface imaging, measurements of thickness and the determination of optical properties (brightness, yellowness, opacity and gloss). According to the optical properties, papers from the VC could be characterized as yellowish and opaque, without gloss. Due to the fact that the VC papers could not be destroyed, we took another set of samples consisting of 10 historical papers (HP) from archival materials, dating from the 16th to nineteenth century, and subjected them to nondestructive, as well as micro-destructive analyses. This was done to supplement the findings of non-destructive analyses of the original collection. Initially, spot tests were performed to determine water absorbency and to identify the presence of lignin and starch in the paper samples. SEM-EDS and XRF were applied for the identification of inorganic elements. FTIR analyses were used to identify the chemical structures of the paper components. Microscopic analyses were performed in two ways: the paper surface was imaged with a digital microscope, and the morphological characteristics of the fibres were studied using an optical microscope. The dominant fibres present were flax and hemp, with a smaller proportion of cotton. Additionally, thick and thin light brown fibres resembling straw were detected. The presence of calcium-containing components, gelatine and alum could be confirmed with SEM-EDS, XFR and FTIR analysis. Comparing the results of analyses performed on two sets of samples a connection was explored by which it was possible to define the characterization of $V C$ papers. The main goal of the study was to document and characterize a specific collection for the future use of researchers of handmade paper or paper conservators. Furthermore, the study may serve as a model approach for other researchers who seek to document the characteristics of paper in their collections.
\end{abstract}

Keywords: Historical paper, Conservation, Non-destructive analysis, Fibres, Optical properties

\footnotetext{
*Correspondence: andragojevic@gmail.com; adragojevic@arhiv.hr

1 Central Laboratory for Conservation and Restoration, Croatian State

Archives, Zagreb, Croatia

Full list of author information is available at the end of the article
}

\section{Introduction}

Janez Vajkard Valvasor (1641-1693), the famous Slovenian polyhistorian, possessed a very valuable library which was stored in the Slovenian castle of Bogenšperg [1]. In 1690, Aleksandar Ignacije Mikulić, the Bishop of Zagreb (1650-1694), bought this priceless book collection and moved it to Zagreb (present-day Croatia). This 
collection became part of the Metropolitana, the library of the Zagreb Archdiocese, and is presently stored in the Croatian State Archives in Zagreb. Valvasor's library is a unique example of a seventeenth century personal library whose contents reflect the interests of its owner. Most of the books are in German, which could indicate that the papers were mostly produced in German-speaking countries [2].

Papers from Valvasor's collection $(V C)$ were handmade papers from an era in which each stage of production had carefully developed steps. During the sixteenth and seventeenth centuries, there existed manufactories with a small number of workers (mostly whole families), while the eighteenth century brought about the evolution of the production process into a series of stages where specialized workers were required. The demand for paper grew, and production expanded and refined along with it, aiming to increase the output and speed up the production process [3].

Throughout its history, paper's basic ingredient, fibre, has been supplemented by additives intended to improve its quality or adapt it to its purpose. Fibres were obtained by a fermentation process from well-worn cloth or rag textiles $[3,4]$. The three basic additives were sizing agents, fillers and colours [4]. Sizing was used to change a paper's resistance to the penetration of a liquid such as ink or other aqueous media. Surface sizing agent, such as gelatine, also improved the paper's strength and abrasion resistance. Sizing was added to paper in two ways. For centuries, the already formed and dried sheets had been immersed in a gelatine solution, but in the late eighteenth century a process was developed whereby sizing of various materials was also, or alternatively, added to the paper pulp before sheet forming. Gelatine was initially introduced in Italy for sizing the writing and printing paper, but in German speaking countries, gelatine was used only for writing paper [5]. For the printing paper, gelatine was commonly used only after the printing process, in cases where the owner specifically ordered and paid for it $[6,7]$. Fillers were added for several reasons: to improve the surface and optical properties, to improve the opacity and brightness and to improve the calendaring capability $[7,8]$. Coloured rags as source of colour can be used to make coloured paper. When the raw material lacked the right colour, the desired result could have been achieved by adding a pigment (engine colour) or dye (pulp colour) to the pulp [8].

One of the first researchers studying historical book papers, William James Barrow, investigated the physical and chemical properties of papers and connected them to durability and resistance to ageing. His research provided an overview of the papermaking process and the composition of papers from the 16th to twentieth century [9]. In the study of the characteristics of handmade papers from the 14th to nineteenth century Barrett et al. used UV/Vis/NIR and XRF spectroscopy to determine the composition of the papers. They also explained the relations between the composition of paper and its properties [10]. The combination of non-destructive and destructive research approaches was used by Maghoub et al. [11] to determine the structure and properties of Islamic paper. Other techniques that were used in testing historical papers are FTIR and Raman spectroscopy [12, 13]. Librando et al. [14] used FTIR for ancient and modern paper characterization and studied the degradation process of cellulose papers. Trafela et al. [15] performed near- and mid-FTIR analyses of historical papers. They related the obtained data to ash, lignin and aluminium content, degree of cellulose polymerization and $\mathrm{pH}$, which were determined by classical analytical methods. The same group of authors applied non-destructive analyses of NIR spectroscopy and made a comparison with analyses of mechanical properties as a parameter of the state of usability, which could be the basis for the elaboration of conservation procedures [16]. Ganzerla et al. used various analytical techniques, including FTIR and SEMEDS, for the characterization of fibres and additives used in paper production in the nineteenth century [17]. In the study by Kostadinovska et al., the combination of optical microscopy and ATR FTIR was shown to be a good tool to analyse historic paper artefacts of unknown composition [18]. They investigated the optical properties of paper by a non-destructive method in order to discover specific materials in the paper. The relationship between the brightness of the paper filler and the brightness of the paper was investigated by Hubbe and Gill [19]. A study of the influence of light and temperature on the optical properties, simulating the conditions of use or storage of documents, proved their negative impact on the stability of paper with cellulose fibres [20].

Non-destructive analysis for the characterization of historical papers is an important approach in the analysis of cultural heritage artifacts [21]. A good example of nondestructive research was provided by a group of researchers who studied a historical library collection in Ravenna, Italy, to assess the extent of the collection's deterioration and to obtain a characterization of the paper. This study also included a calculation ofto the collection lifetime which was done by combining the findings of chemical properties with environmental conditions using the dose-response function [22, 23]. Strlič et al. established a database of the mechanical and chemical properties of paper which describes the interdependence of composition and degradation, and which in turn may have an impact on conservation research and practice [24]. In 1984, Lahavier explained the application of scientific 
research on museum objects for the purpose of dating, establishing provenance and revealing the composition of materials [25]. Rizutto et al. elaborated the research methodology in investigating cultural-historical objects and defined it in three basic steps: visual inspection, nondestructive analysis and finally, semi-destructive and microscopic analysis (26]. Kostadinovska et al. studied historical papers from eighteenth and nineteenth century books and artistic cartoons [27, 28]. Comparisons were given for both sets of materials of the results of spot tests, ATR-FTIR and micro-Raman analysis. This work contributed to the design of the conservation-restoration protocols. Changes in paper properties before and after the conservation-restoration procedure were also investigated by Vodopivec Tomažič et al. [6]. The research of general and optical properties, FTIR analysis and other analyses of books and papers were carried out on several copies of Valvasor's book The Glory of the Duchy of Carniola from 1689.

Samples of historical papers from different periods are very difficult to obtain and collect. Their size and quantity are limited and often insufficient for specific analyses. In the case of analysis of HP samples, one of them is from Valvasor's collection itself (1D), so an accurate comparison was possible. Valvasor was a Slovenian nobleman who sold his collection to the Zagreb Archdiocese in the seventeenth century, and there has been no change in ownership since then. Present-day Slovenia and Croatia are countries that were connected by the same empires and states for centuries, so it is natural that we searched for samples which are found in the national archives of both countries. Research described in this paper is part of a broader study aimed at finding the most useful analyses for characterizing historical handmade papers and thus assisting future researchers and conservators in their work.

$V C$ papers were first documented and a database of the working name Valper $i$ was created. As Valvasor's collection is a cultural heritage in which case the conservationrestoration protocol bars destruction, it was not possible to perform destructive and micro-destructive analyses. As non-destructive analyses are insufficient for characterization, we collected a parallel set of 10 samples of handmade paper dating from the 16th to the nineteenth century. Destructive analyses were performed on this sample, with the aim of supplementing the picture of the structure and composition of $V C$ papers. The task was to find connections between the results of non-destructive and destructive/micro-destructive analysis which could ultimately be used as a tool to characterize the Valvasor Collection papers. Papers from the $V C$ were selected randomly from six books belonging to the collection.

\section{Materials and methods}

The first stage of our study consisted of a thorough visual examination of papers from Valvsasor's collection $(V C)$, which was followed by non-destructive analyses of these samples. In the second stage, micro-destructive analyses were performed on the second set of samples, i.e. fragments of historical papers $(H P)$, in order to supplement the findings of non-destructive analyses. The applied methods were selected according to standardized methodology, with respect to sample size and results desired.

\section{Materials-papers from Valvasor's collection (VC)}

The papers subjected to non-destructive analytical methods is from the $V C$ and are dated in the period from 1662 to 1689. All papers in this group are from the books, except the ones marked 1ND, which are archival documents kept in the Croatian State Archives. Four of the items are printed books (2ND, 4ND, 6ND and 7ND), two are manuscripts (1ND and 3ND) and one is from the Valvasor graphic collection (5ND). Sampling was performed according to the visual differences (colours and surface structure by touch) of the paper, randomly throughout each of the books. A total of 144 papers were analysed (Table 1).

\section{Materials-Historical paper samples (HP)}

The second group of analysed paper samples, named historical papers (HPS) are fragments. They were found separately in the Croatian State Archives and Archives of the Republic of Slovenia. Being without classification, they were not intended for storage. Five samples (3D, 4D, $6 \mathrm{D}, 8 \mathrm{D}$, and $9 \mathrm{D}$ ) are without any writing on them, two are fragments of manuscripts (5D and 10D) and the rest are paper supports for the graphic collection and blotting paper for ink and print form. HPs are mostly only roughly dated according to the type of manuscript or the date from the archive in which they were found and cover the time span from the 16th to the nineteenth century. They are marked 1D to 10D and are listed in Table 2.

\section{Characterization methods}

Analyses performed included visual examination, microscopic imaging of the paper surface and measuring the thickness and optical properties of the $V C$ papers. $H P$ fragments, in addition to the above methods, were subjected to micro-destructive spot tests using different reagents, $\mathrm{pH}$ measurements and morphological analysis of the fibres. The following instrumental analyses were performed on the HP fragments: SEM-EDS (scanning electron microscopy with energy dispersive spectroscopy), XRF (X-ray fluorescence) ATR-FTIR (attenuated total reflection Fourier transform infrared spectroscopy). 
Table 1 Selected papers from seven books of the VC arranged chronologically according to their origin

\begin{tabular}{|c|c|c|c|}
\hline $\begin{array}{l}\text { Sample } \\
\text { group } \\
\text { mark }\end{array}$ & Type of material; title, date, author, number of pages & Inventory number & $\begin{array}{l}\text { No. of } \\
\text { papers } \\
\text { analysed }\end{array}$ \\
\hline $1 \mathrm{ND}$ & $\begin{array}{l}\text { Document manuscript; Notary of the Kingdom of Dalmatia, Croatia and Slavonia, 1662, Ivan Zakmardi } \\
\text { (1600-1667), } 10 \text { (all documents in folder are written on visually identical paper) }\end{array}$ & HR-HDA 11, box No. 3 & 10 \\
\hline 2ND & $\begin{array}{l}\text { Printed book; Topographia arcium Lambergianarum id est arces, castella et dominia in Carniolia habita } \\
\text { possident comites a Lamberg; Bagenspergi, loannem Weichardvm Valvasor, 1679, } \\
50 \text { (the papers are visually identical throughout the book block) }\end{array}$ & M11650 & 10 \\
\hline $3 N D$ & $\begin{array}{l}\text { Manuscript; A book of sketches for a book, Topographia Archiducatus Carinthiae modernae, before } \\
\text { 1681,231 (papers from the book of sketches are visually different throughout the book block) }\end{array}$ & M 198 & 14 \\
\hline 4ND & $\begin{array}{l}\text { Printed book; Topographia Archiducatus Carinthiae modernae, Durch Johann Weichard Valvasor, } \\
\text { Wagensberg in Krain im iahr 1681, Zu Laybach, Gedr. Bey Johann Baptista Mayr, 1681, } 228 \text { (papers } \\
\text { from the book are visually different throughout the book block) }\end{array}$ & M11640 & 14 \\
\hline $5 \mathrm{ND}$ & $\begin{array}{l}\text { Graphics; Valvasor's graphic collection, 1685, } 210 \text { (the graphics were printed on visually different } \\
\text { papers) }\end{array}$ & M158, Tomus VII & 61 \\
\hline $6 \mathrm{ND}$ & $\begin{array}{l}\text { Printed book; Topographia Archiducatus Carinthiae antiquae \& modernae completa: Das ist } \\
\text { Vollkommene und gründliche Land - Beschreibung des berühmten Erz - Herzogthums Kärnd- } \\
\text { ten; Nürnberg, In Verlegung Wolfgang Moritz Endters, 1688, } 274 \text { (the papers are visually identical } \\
\text { throughout the book block) }\end{array}$ & M11527 & 10 \\
\hline 7ND & $\begin{array}{l}\text { Printed book; Die Ehre dess Hertzogthums Crain; Johann Weichard Valvasor, Volume 3; Laybach, Zu } \\
\text { finden bey W.M.Endter, Buchhändlern in Nürnberg, 1689, } 1129 \text { (papers are different visually and by } \\
\text { touch throughout the book block) }\end{array}$ & M1124 & 25 \\
\hline
\end{tabular}

ND non-destructive analyses

Table 2 The list of HP fragments

\begin{tabular}{|c|c|c|c|}
\hline Sample mark & Description & Origin of samples & Date \\
\hline 1D & $\begin{array}{l}\text { Paper support for graphic collection Valvasor collec- } \\
\text { tion; inventory number M158 }\end{array}$ & Metropolitan Library Archdiocese of Zagreb & 1685 \\
\hline $2 \mathrm{D}$ & Blotting paper for ink & Archives of the Republic of Slovenia & First half of the nineteenth century \\
\hline $3 \mathrm{D}$ & $\begin{array}{l}\text { Fragment without handwritten script; Found in } \\
\text { Križevci County, } 1\end{array}$ & Croatian State Archives & Sixteenth-seventeenth century \\
\hline $4 \mathrm{D}$ & $\begin{array}{l}\text { Fragment without handwritten script; Found in } \\
\text { Križevci County; } 2\end{array}$ & Croatian State Archives & Sixteenth-seventeenth century \\
\hline $5 \mathrm{D}$ & $\begin{array}{l}\text { Fragment of a letter with handwritten script; Found in } \\
\text { Križevci County; } 3\end{array}$ & Croatian State Archives & 1745 \\
\hline $6 \mathrm{D}$ & $\begin{array}{l}\text { Fragment without handwritten script; Protocol } \\
\text { 1763-1781 }\end{array}$ & Archives of the Republic of Slovenia & Eighteenth century \\
\hline $7 D$ & $\begin{array}{l}\text { Fragment without handwritten script; Print form; } \\
1806\end{array}$ & Archives of the Republic of Slovenia & Nineteenth century \\
\hline $8 \mathrm{D}$ & Fragment without handwritten script; 1807 & Archives of the Republic of Slovenia & Nineteenth century \\
\hline $9 \mathrm{D}$ & $\begin{array}{l}\text { Fragment without handwritten script; Found in } \\
\text { Križevci County, } 4\end{array}$ & Croatian State Archives & Sixteenth-seventeenth century \\
\hline $10 \mathrm{D}$ & $\begin{array}{l}\text { Fragment of the handwritten script document; Found } \\
\text { in Križevci County, } 15\end{array}$ & Croatian State Archives & Sixteenth century \\
\hline
\end{tabular}

$D$ destructive analyses

In Table 3, we present the list of methods performed on both sets of paper samples ( $V C$ and $H P)$.

\section{Visual examination}

Visual examination included measuring the dimensions of the papers, dimensions and orientation of the paper mould. Photographs were taken in transmitted light to define and measure mould laid, chain line spacing and watermarks.

\section{Microscopic analyses}

Microscopic analyses to identify fibres in paper samples were performed on a Micros Austria type MCx500 optical microscope with $4 \times, 10 \times, 40 \times$ and $100 \times$ lenses and 
Table 3 List of analyses performed on the samples

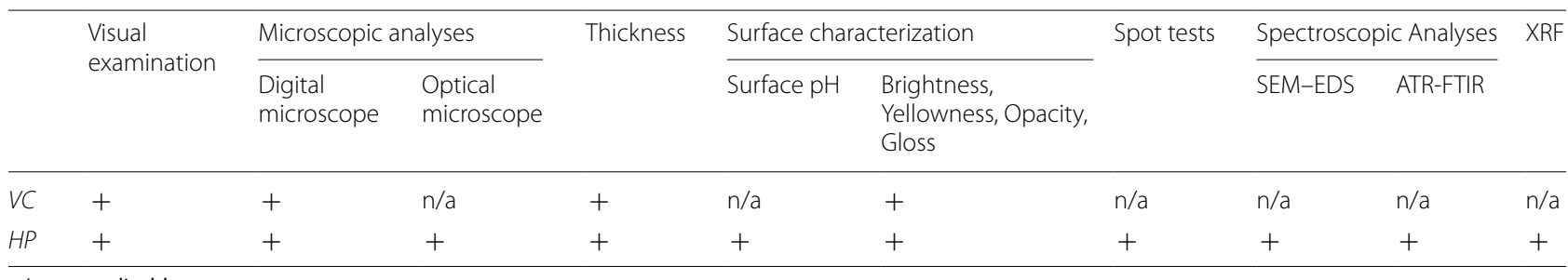

n/a not applicable

a $10 \times / 22$ magnification eyepiece under transmitted light with and without staining, according to the TAPPI standard T 401 [30]. Fibre identification was based on morphological characteristics [31, 32].

The imaging of the paper surface was performed with digital microscope imaging at a magnification of $500 \times$ with the model Dino-Lite AM4013 MT5.

\section{Thickness}

The thickness of paper was measured with a micrometre according to the standard EN ISO 534:2005 [32] by inserting a sample between two parallel metal plates, measuring in the range of $0-10 \mathrm{~mm}$ with an accuracy of $0.001 \mathrm{~mm}$. The device model Enrico Toniolo S.r.l. DGTB001 Thickness Gauge was used.

\section{Surface characterization}

In addition to visual examination, microscopic analyses and measuring of the thickness of the papers, the characterization of the paper surface was carried out by measuring surface $\mathrm{pH}$ and optical properties. The optical properties measured were brightness, yellowness, opacity and gloss.

The $\mathrm{pH}$ of the paper surface was measured with a Mettler Toledo Seven 2Go Advanced portable pH metre with an InLab Surface PRO-ISM surface measurement electrode in 5 different places as prescribed by the TAPPI T529 standard [34].

The X-Rite EXact device was used to measure the optical properties of the samples. The measurement of brightness was carried out according to the standard ISO 2470:1999 [35]. It is defined as the ratio between the reflection of diffuse blue light from the surface of a paper sample at $457 \mathrm{~nm}$ and the reflection of an ideal reflecting body and is expressed as percentage. The measurement of yellowness is used to estimate the white and almost white samples, and it is expressed as percentage. The opacity measures light impermeability in the paper and is expressed as percentage. Opacity of the paper was determined according to the standard ISO 2471: 1998 [36]. The gloss of the paper is measured by directing a beam of constant power at an angle of $75^{\circ}$ to the test surface and by monitoring the reflected light. Paper gloss measurements were carried out in accordance with standard ISO 8254-1:2009 [37] using an Elcometer 407 Statistic Glossmeter.

\section{Spot tests}

Spot tests are short, quick tests which cause changes in the test sample under the influence of a reagent.

The water absorption test was performed according to the TAPPI standard T492 pm-76 [38]. This method detects the time required to absorb water in uncoated or lightly coated papers. Distilled water was dropped from a height of $1 \mathrm{~cm}$ onto the surface of the paper, and the time until the water droplet was completely absorbed was measured.

The spot test for starch in the paper was determined with a solution of potassium iodide according to TAPPI standard T419 [39]. The solution was dropped on a paper surface, and the change in colour was observed with the naked eye.

The presence of lignin was determined by using phloroglucinol solution as a reagent according to TAPPI standard T 401 [30]. The phloroglucinol solution stains the wood fibres and other lignin-containing fibres in proportion to the amount of lignin. The colour change was assessed by the naked eye under a loupe.

The Herzberg stain test was performed according to TAPPI standard T 401 and ISO 9184-3 [30, 40]. A drop of reagent was added to the fibres pulled from the water suspension of a paper sample and placed on a microscope slide. This test for fibre identification is based on the colour change; chemical pulps acquire a blue tint, groundwood is yellow, while rag pulp fibres turn pink, light red, or peach to deep red [40].

\section{Spectroscopic analyses}

Scanning electron microscopy with energy dispersive spectroscopy (SEM-EDS)

SEM-EDS is an analytical technique for elemental characterization of samples. In our study SEM-EDS analyses were conducted using a Coxem EM30AXPlus with magnification from $20-100,000 \times$ and spatial resolution $<5 \mathrm{~nm}$. The X-ray detection EDS technique is used 
to qualitatively determine the elemental composition of a sample visually identified by SEM.

\section{$X$-ray fluorescence analysis (XRF)}

$\mathrm{XRF}$ is a method for qualitative and quantitative detection of inorganic elements in a sample. The samples were analysed using an Artax BruXRF spectrometer manufactured by Bruker. The recording conditions were $50 \mathrm{kV}$ and $700 \mu \mathrm{A}$. A helium purge was also used during recording to detect the fluorescence of the lightest elements (Na-Si). The anode of the X-ray tube was $\mathrm{Rh}$. The X-ray beam was directed by a $0.6 \mathrm{~mm}$ diameter pinhole collimator. The $\mathrm{Rh}$ and $\mathrm{Zr}$ visible in the spectra originated from the X-ray tubes and collimators, which means that they were not present in the sample.

EDS is a surface technique, while XRF is a semi-quantitative method.

\section{Fourier transform infrared spectroscopy (FTIR)}

FTIR was used to identify major paper components and to assess the presence of other compounds. FTIR spectra of historical paper samples were recorded using an FTIR spectrometer Spectrum GX, I-Series (Perkin Elmer, Waltham, MA, USA) equipped with an attenuated total reflection (ATR) cell and a diamond crystal $(n=2)$. The operation of the apparatus was controlled through Spectrum and Image software for FTIR. The spectra were recorded in reflection mode over the spectral range $4000-500 \mathrm{~cm}$ with a resolution of $4 \mathrm{~cm}^{-1}$ in the ATR technique and were averaged from 64 scans. The recorded spectra of $H P$ samples were compared with the selected reference spectra recorded for reference samples of cotton, flax, hemp, softwood and hardwood cellulose, gelatine, starch, clay and calcium carbonate. Additionally, identification of the characteristic absorption bands was performed by comparing the obtained spectra with the published spectra $[14,18,41]$.

\section{Statistical analysis of data}

Multiple regression and one-way analysis of variance (ANOVA) were performed on the data with the probability level for statistical significance set at $p=0.05$. The thickness and optical properties of papers from $V C$ and $H P$ samples were compared using ANOVA. The relationship between the properties of HP samples was assessed by regression analysis, where each of the optical properties was used as a dependent variable, whereas thickness and $\mathrm{pH}$ were independent variables. The correlation between the optical properties, thickness, $\mathrm{pH}$ content and water absorption were determined by the Pearson correlation coefficient.

\section{Results and discussion}

\section{Visual inspection}

The $V C$ papers were visually examined, their dimensions were measured, and the dimensions and orientation of the paper mould were determined (Table 4). Photographs were taken in transmitted light to define and measure mould laid and chain line spacing and watermarks. The chain line spacing ranged from 22 to $32 \mathrm{~mm}$, while the density of the laid lines ranged from 14 lines $/ 20 \mathrm{~mm}$ to 20 lines $/ 20 \mathrm{~mm}$. Most of the watermarks are a coat of arms, two of them identify the origin of the paper mill for historical hand-made papers, while the others were assigned a label according to the IPH standard [42]. The dimensions of the paper mould were also measured on HP samples (Table 5). In these samples chain line spacing was in the range of $22-32 \mathrm{~mm}$, and laid lines were in the range of $14-20$ lines $/ 20 \mathrm{~mm}$.

Six watermarks were found, and two were identified according watermark databases [43, 44]. One watermark from $V C$ papers depicting the coat of arms of Carinthia most probably belongs to St. Ruprecht paper mill near Klagenfurt in Carinthia (present-day Austria) and is dated into the seventeenth century (Fig. 1a) [44]. The other watermark found in a group of $H P$ samples most probably belongs to the paper mill of Valentino Galvani from Pordenone (present-day Italy) and is dated into the nineteenth century (Fig. 1b) [45].

By analysing the dimensions of the papers, the imprint of the paper mould and the position of the watermark, we were able to conclude that, in all the researched books, the $V C$ papers originate from two paper mould formats. The dimensions of the smaller format are $245-278 \times 360-380 \mathrm{~mm}$ and those of the larger one are $360-370 \times 420-440 \mathrm{~mm}$. The above examinations by visual inspection led to several conclusions. The same watermarks on different $V C$ papers do not have the same dimensions, which indicates that the manufacturer used several paper moulds for the same type of paper. Four watermarks are clearly visible on ten $H P$ samples, only one of which has been identified until now. Other fragments are dated according to the dating of the archival fund in which they were found and according to the type of manuscript. We could observe in several examples (3ND, 4ND, and 5ND) that the endpapers in front and back of the book were made from the same type of watermarked paper (coat of arms of Carinthia), while the leaves or folios of the book block were from different types with different watermarks. Among the total of $144 \mathrm{VC}$ research papers, watermarks were found on 37, of which 28 were coats of arms. 
Table 4 VC papers: sheet dimensions, watermarks, dimensions and orientation of the mould

\begin{tabular}{|c|c|c|c|c|c|c|c|}
\hline $\begin{array}{l}\text { Sample group } \\
\text { mark }\end{array}$ & $1 \mathrm{ND}$ & $2 N D$ & $3 N D$ & $4 N D$ & 5ND & 6ND & $7 N D$ \\
\hline Dating & 1662 & 1679 & Prior to 1681 & 1681 & 1685 & 1688 & 1689 \\
\hline $\begin{array}{l}\text { Paper, width } \\
\mathrm{x} \text { height } / \mathrm{mm}\end{array}$ & $\begin{array}{c}410-420 \\
\times 320 \\
\end{array}$ & $278 \times 190$ & $278 \times 179$ & $286 \times 180$ & $360-370 \times 420-440$ & $\begin{array}{c}245 \text { and } 440 x \\
368\end{array}$ & $240 \times 373-376$ \\
\hline $\begin{array}{l}\text { Place of } \\
\text { origin or use } \\
\text { of paper }\end{array}$ & Zagreb & Bogenšperk & Bogenšperk & $\begin{array}{c}\text { Bogenšpe } \\
\text { rk }\end{array}$ & Bogenšperk & Nüremberg & Nüremberg \\
\hline $\begin{array}{l}\text { Chain lines; } \\
\text { orientation, } \\
\text { distance } \\
\text { between } \\
\text { chain } \\
\text { lines } / \mathrm{mm} \\
\end{array}$ & $\begin{array}{c}\text { Vertical } \\
20-21 \\
\mathrm{~mm}\end{array}$ & $\begin{array}{c}\text { Horizontal } \\
22,23,28 \\
\mathrm{~mm}\end{array}$ & $\begin{array}{l}\text { Horizontal } \\
22-28 \mathrm{~mm}\end{array}$ & $\begin{array}{c}\text { Horizontal } \\
22,23,24 \\
\mathrm{~mm}\end{array}$ & Horizontal, other vertical $16-28 \mathrm{~mm}$ & $\begin{array}{c}\text { Horizontal, } \\
\text { covering sheet, } \\
\text { endleaf; vertical } \\
\text { book block } \\
\text { leaves; } 28-29 \\
\mathrm{~mm}\end{array}$ & Horizontal 23-28 mm \\
\hline $\begin{array}{l}\text { Laid lines; } \\
\text { number of } \\
\text { lines over a } \\
\text { distance of } \\
20 \mathrm{~mm}\end{array}$ & $\begin{array}{c}18,20 \\
24\end{array}$ & 18,20 & $14,16,18,20$ & 18,20 & $16,18,20,22,24$ & 20,22 & $16,18,20$ \\
\hline $\begin{array}{l}\text { Photo in } \\
\text { transmitted } \\
\text { light } \\
\text { Watermark } \\
\text { schematics, } \\
\text { watermark } \\
\text { dimensions, } \\
\mathrm{H} \times \mathrm{W} / \mathrm{mm}\end{array}$ & $\begin{array}{c}\text { Pes } \\
59 \mathrm{xm} \\
\text { Bishop's } \\
\text { crosier }\end{array}$ & $\begin{array}{l}89 \times 47 \mathrm{~mm} \\
85 \times 23 \mathrm{~mm} \\
64 \times 33 \mathrm{~mm} \\
64 \\
64 \times 44 \mathrm{~mm}\end{array}$ & 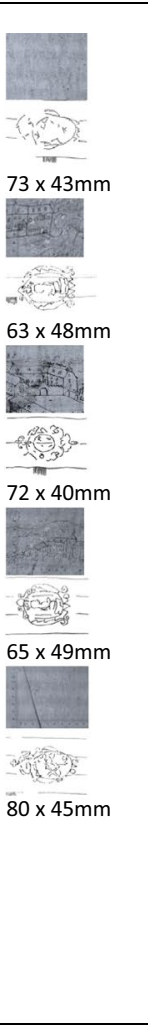 & 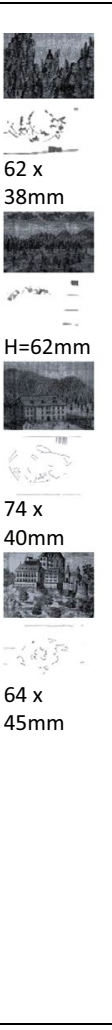 & 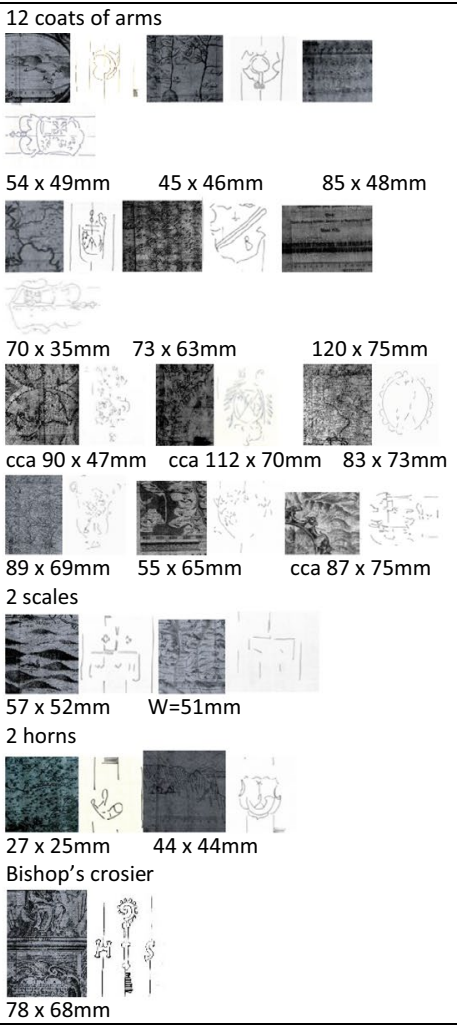 & $\begin{array}{l}\text { 65 x 28mm } \\
\text { Hermes cross } \\
54 \times 28 \mathrm{~mm} \\
54 \times 31 \mathrm{~mm}\end{array}$ & 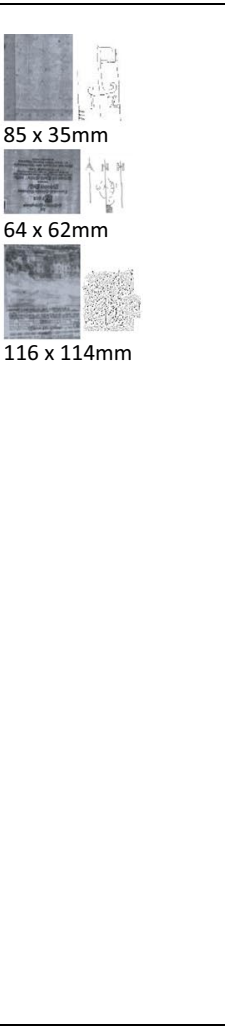 \\
\hline
\end{tabular}

\section{Microscopy analysis}

Microscopic analysis was performed in two ways. We used digital microscopy to observe specific fibres in the paper and an optical microscope for morphological analysis of the fibres. Sampling for morphological fibre analysis is micro-destructive from the conservator's perspective, a procedure that later requires minor conservation interventions. Such analysis is tolerated if the papers are intended for further conservation work.

The surface of the paper was analysed with a digital microscope on both $V C$ papers and $H P$ samples, while fibres were analysed by an optical microscope only for $H P$ samples. Several types of such fibres were detected on both sets of samples. Thus, blue, red, light brown, dark brown and black-brown fibres appear in all examined samples. By measuring the width of the fibres, it was observed that belong to two types, a thin $(<150 \mu \mathrm{m})$ and a thick one $(>150 \mu \mathrm{m})$, as shown in Figs. 3 and 4 . The inspection of papers by digital microscope revealed some specific fibres which appear to stand out from the majority of white fibres (Fig. 2). Among the HP samples, the largest amount of different types of fibres was detected 
Table 5 HP samples: sheet dimensions, watermarks, dimensions and orientation of mould

\begin{tabular}{|c|c|c|c|c|c|c|c|c|c|c|}
\hline Sample mark & $1 \mathrm{D}$ & $2 \mathrm{D}$ & $3 D$ & 4D & $5 \mathrm{D}$ & $6 \mathrm{D}$ & $7 D$ & $8 \mathrm{D}$ & $9 D$ & $10 \mathrm{D}$ \\
\hline $\begin{array}{l}\text { Paper height } \mathrm{x} \\
\text { width } / \mathrm{mm}\end{array}$ & $390 \times 118$ & $324 \times 200$ & $389 \times 116$ & $309 \times 200$ & $423 \times 331$ & $431 \times 325$ & $597 \times 370$ & $532 \times 381$ & $389 \times 121$ & $90 \times 110$ \\
\hline $\begin{array}{l}\text { Chain lines; } \\
\text { orientation, } \\
\text { distance between } \\
\text { chain lines / mm }\end{array}$ & $\begin{array}{c}\text { Not } \\
\text { readable }\end{array}$ & $\begin{array}{l}\text { Vertical } \\
24 \mathrm{~mm}\end{array}$ & $\begin{array}{l}\text { Vertical } \\
27 \mathrm{mmm}\end{array}$ & $\begin{array}{l}\text { Vertical } \\
24 \mathrm{~mm}\end{array}$ & $\begin{array}{l}\text { Vertical } \\
22 \mathrm{~mm}\end{array}$ & $\begin{array}{l}\text { Vertical } \\
32 \mathrm{~mm}\end{array}$ & $\begin{array}{l}\text { Vertical } \\
26 \mathrm{~mm}\end{array}$ & $\begin{array}{l}\text { Vertical } \\
24 \mathrm{~mm}\end{array}$ & $\begin{array}{l}\text { Vertical } \\
27 \mathrm{~mm}\end{array}$ & $\begin{array}{l}\text { Not } \\
\text { readab } \\
\text { le }\end{array}$ \\
\hline $\begin{array}{l}\text { Laid lines; number } \\
\text { of lines over a } \\
\text { distance of } 20 \mathrm{~mm}\end{array}$ & 14 & 16 & 14 & 16 & 16 & 18 & 16 & 20 & 14 & $\begin{array}{l}\text { Not } \\
\text { readab } \\
\text { le }\end{array}$ \\
\hline $\begin{array}{l}\text { Photo in } \\
\text { transmitted light }\end{array}$ & & & & & & & & & & \\
\hline $\begin{array}{l}\text { Watermark } \\
\text { schematics, } \\
\text { watermark } \\
\text { dimensions }\end{array}$ & Not caught & $\begin{array}{l}\left|\begin{array}{l}\mid \\
\mid\end{array}\right| \\
\mathrm{H}=50 \mathrm{~mm} \\
\mathrm{~W}=27 \mathrm{~mm}\end{array}$ & & $\begin{array}{l}\mathrm{H}=50 \mathrm{~mm} \\
\mathrm{~W}=27 \mathrm{~mm}\end{array}$ & $\begin{array}{c}\mathrm{H}= \\
137 \mathrm{~mm} \\
W=92 \mathrm{~mm}\end{array}$ & $\begin{array}{l}\text { Watermark: } \\
\mathrm{H}=65 \mathrm{~mm} \\
\mathrm{~W}=38 \mathrm{~mm}\end{array}$ & 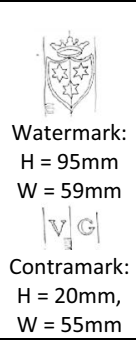 & $\begin{array}{l}\mathrm{H}=122 \mathrm{~mm} \\
\mathrm{~W}=63 \mathrm{~mm}\end{array}$ & Not caught & $\begin{array}{c}\text { Not } \\
\text { caught }\end{array}$ \\
\hline
\end{tabular}
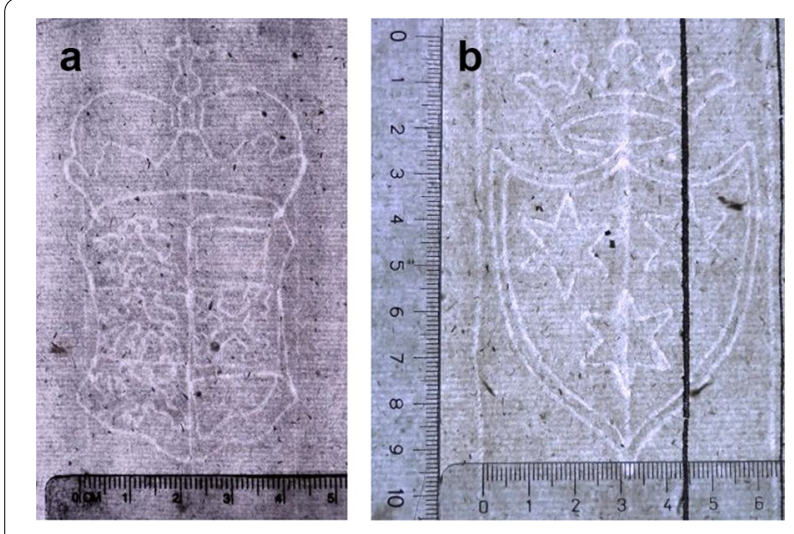

Fig. 1 Identified watermark from a) VC paper 5ND b) HP sample 7D

in the sample 2D (Fig. 2). In samples 3D, 4D, 6D and 8D, thick light brown fibres were found, which could indicate that they are straw fibres. Thin fibres are present in samples 5D, 7D and 10D.

From the non-destructive microscopic imaging of the raw historical papers from Valvasor's collection $(V C)$, as well as the fragments (HPs), we see that the most specific fibres can be described as being thin (less than $150 \mu \mathrm{m}$ ) and light brown. Blue and red fibres were also found in a number of samples and, according to width, they can also be characterized as thin (Fig. 3a, b).

A thick light brown fibre was also observed, with a width of over $400 \mu \mathrm{m}$ in some places, which looks like

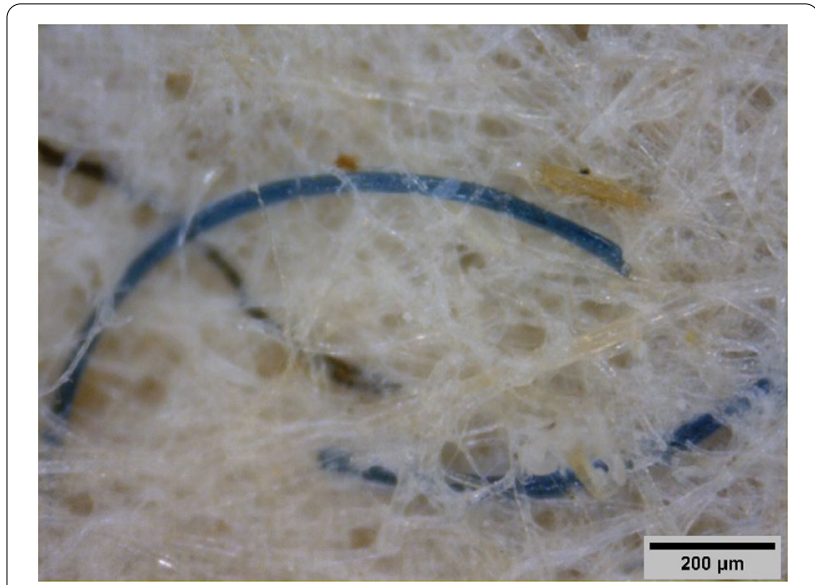

Fig. 2 Image of fibres detected by digital microscope on the surface of the HP sample 2D

straw (Figs. 3d, 4a) [46]. Sporadically, thicker fibres were found deep in the structure of the papers, making it difficult to measure them accurately. White fibres were, however, clearly visible and their width was measured, ranging from $11 \mu \mathrm{m}$ to $29 \mu \mathrm{m}$ (Fig. 4). They probably belong to two types of fibres specific to the seventeenth century, i.e. hemp and flax [31].

Flax and hemp fibres and, in some cases, cotton fibres are visible by the optical microscope (Fig. 5a). The flax fibre cells appear as long, transparent, cylindrical tubes 

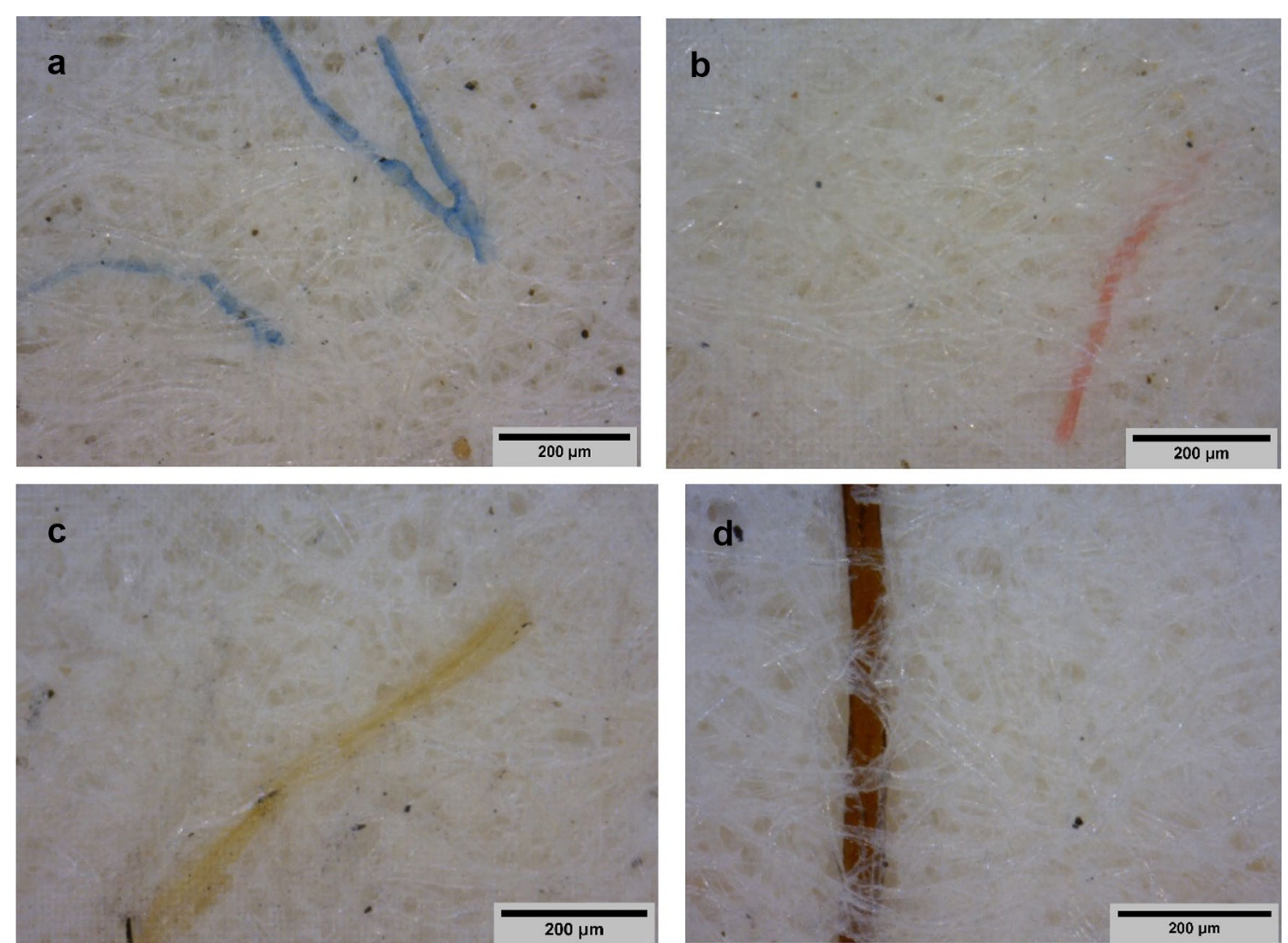

Fig. 3 Image of fibres detected by digital microscope on the surface of $V C$ papers: a paper 7ND, blue fibre $(W=11 \mu \mathrm{m})$, b paper 3ND, red fibre $(\mathrm{W}=18 \mu \mathrm{m})$, $\mathbf{c}$ paper 5ND, thin light brown fibre $(\mathrm{W}=48 \mu \mathrm{m})$, and $\mathbf{d}$ paper 9ND, thin dark brown fibre $(\mathrm{W}=14 \mu \mathrm{m}-54 \mu \mathrm{m})$
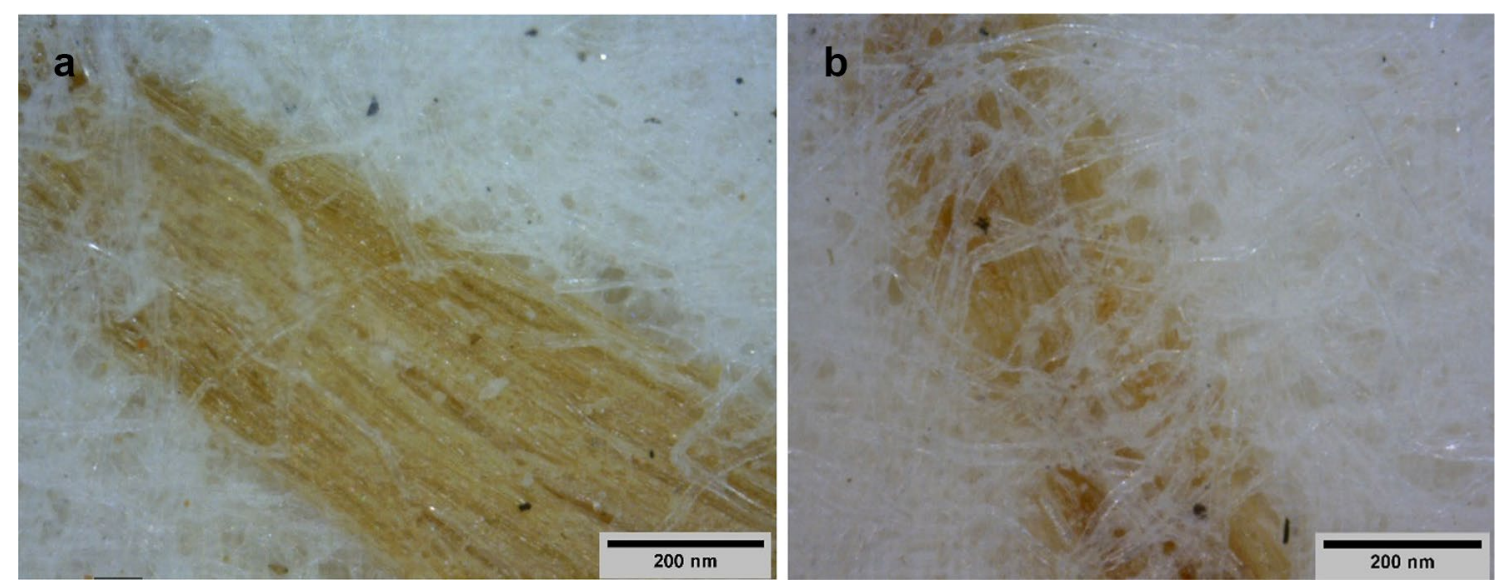

Fig. 4 Images of fibres detected by digital microscope on the surface of the $V C$ papers a paper 2ND, thick light brown fibre (W=355 $\mu \mathrm{m}$; $\mathrm{W}=410 \mu \mathrm{m})$ and $\mathbf{b}$ paper $7 \mathrm{ND}$, white fibres $(\mathrm{W}=9 \mu \mathrm{m} ; \mathrm{W}=18 \mu \mathrm{m})$

that may be smooth or striated lengthwise. The width of the fibre can vary several times along its length. There are swellings or nodes at many points, and the fibres show characteristic cross-markings. The fibre cell has a lumen or canal running through the centre; the lumen is narrow but clearly defined and regular in width [32]. The 

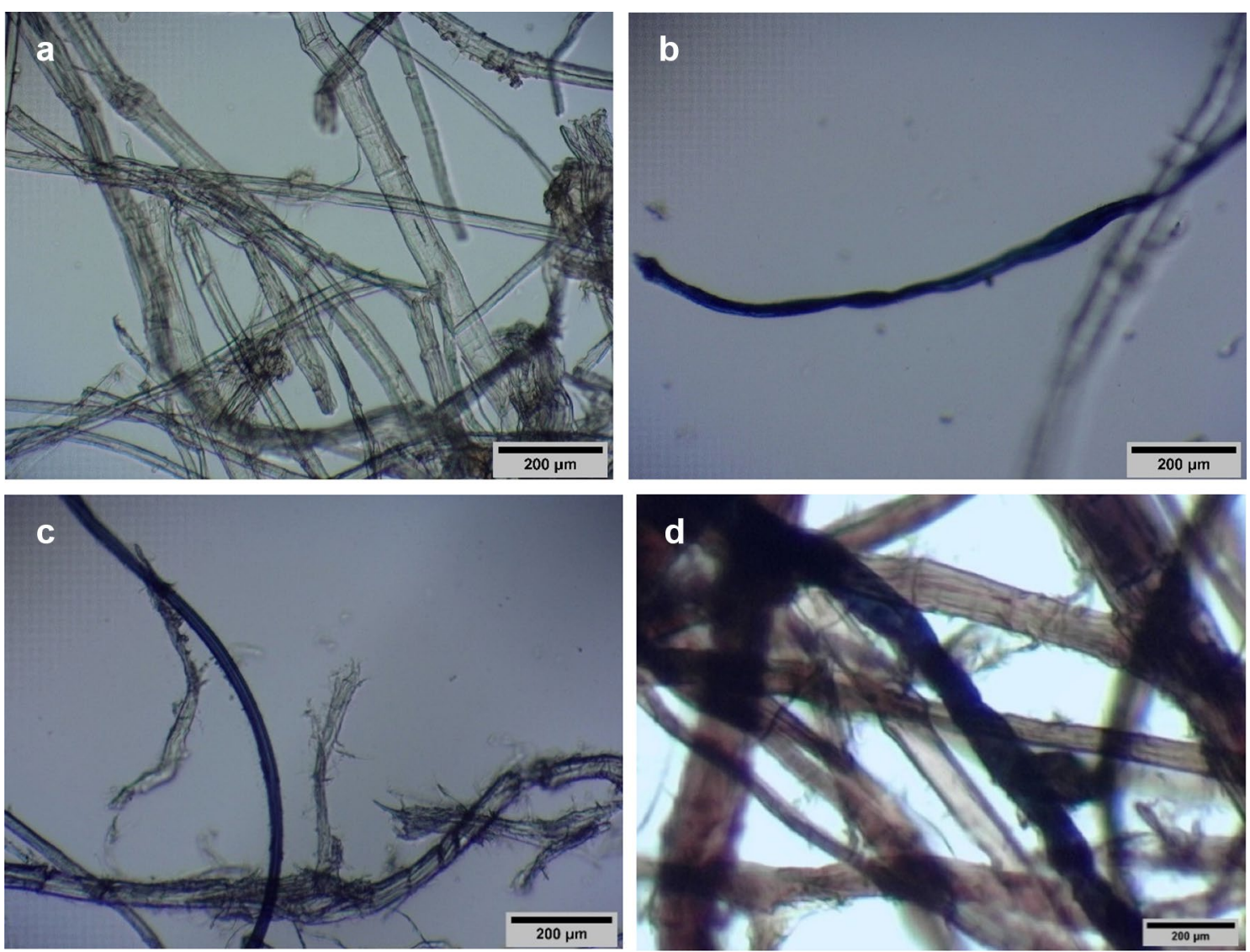

Fig. 5 Paper fibres as ween by the optical microscope a flax and hemp fibres in water, $\times 100$, sample 3D; $\mathbf{b}$ blue cotton fibre in water, $\times 100$, sample 3D; c blue silk fibre in water, $\times 100$, sample 10D; $\mathbf{d}$ flax and hemp in Herzberg reagent, $\times 100$, sample 9D

individual cells of hemp are, on average, $13-26 \mathrm{~mm}$ long. They are cylindrical in shape, with joints, cracks, swellings and other irregularities on the surface. The central canal or lumen is broader than that of flax, and the ends of the cells are blunt [31]. The fibres taken from HP samples were subjected to the Herzberg stain test for identification purposes [30, 40]. Most of the analysed fibres were coloured reddish grey (Fig. 5d), compared with standard samples.

\section{Thickness}

The thickness of paper is one of its basic properties. The measurements of the thickness of $V C$ papers were limited to the area along the edges of the papers and the area without a plate imprint. This thickness varied mostly between 0.1 and $0.2 \mathrm{~mm}$, although thickness below $0.1 \mathrm{~mm}$ (samples $2 \mathrm{ND}$ and $5 \mathrm{ND}$ ) and over $0.2 \mathrm{~mm}$ were also occasionally observed. A thickness of more than $0.5 \mathrm{~mm}$ was determined on a composite sample, where paper is glued to the textile base material. It was also noted that, within the same book, a small difference in thickness was observed between the endpapers and papers within the book block.

The measured values of paper thickness in six HP samples range from 0.16 to $0.2 \mathrm{~mm}$, and in the remaining four samples they are greater than $0.2 \mathrm{~mm}$.

ANOVA showed significant difference in the values of paper thickness in $V C$ and $H P$ samples $(\mathrm{p}=0.0077)$, suggesting that papers in the $V C$, which are thinner, differ from comparative historical papers.

\section{Surface characterization \\ $\mathrm{pH}$}

The acidity/alkalinity of the paper is a key information needed to preserve and protect the paper from degradation. Therefore, the determination of acidity/alkalinity is common in paper conservation. $\mathrm{pH}$ measuring plays an important role in detecting paper degradation, as was described in a study of the kinetic analysis of the ageing process [47]. This study showed that the degradation rate depends on the moisture and acidity of the paper.

A method according to the TAPPI T529 standard was applied to HP samples only [32]. This method prescribes 
measurements by applying a drop of distilled water to an appropriate place and measuring the $\mathrm{pH}$ in that drop. Most of the measured values were found to be in the neutral or slightly acidic range, between 6 and 7. Three samples-2D, 3D and 9D-stand out, because their values were less than 6 , and one of them (3D) has a $\mathrm{pH}$ value of 5 . Values slightly above 7 were measured in two samples (1D and 6D).

Measurement of $\mathrm{pH}$ on the surface of $H P$ samples revealed some destructiveness of the method due to damage caused by water. In using this method, stains may occur due to the water-soluble components in the paper or/and inks, along with dust and dirt, which is often incorporated deeply in the historical paper, leaving tidelines. Such stains can be in certain cases removed by conservation-restoration procedures, but because $V C$ papers were not intended for further procedures, $\mathrm{pH}$ measurements were not applied to them.

Table 6 Results of multiple regression analysis for HP samples: multiple regression coefficient (R), coefficient of determination $\left(R^{2}\right)$, adjusted $R^{2}$, $p$-values

\begin{tabular}{lllll}
\hline & Brightness & Yellowness & Opacity & Gloss \\
\hline Multiple R & 0.78 & 0.74 & 0.89 & 0.63 \\
$\mathrm{R}^{2}$ & 0.61 & 0.55 & 0.80 & 0.40 \\
Adjusted $\mathrm{R}^{2}$ & 0.50 & 0.41 & 0.74 & 0.23 \\
p-value & 0.037 & 0.063 & 0.004 & 0.169 \\
p-value-thickness & 0.299 & 0.323 & 0.009 & 0.582 \\
p-value-pH & 0.015 & 0.025 & 0.256 & 0.08
\end{tabular}

\section{Optical Properties}

Optical properties were measured to complement the visual evaluation of papers with the analytical method. Brightness, yellowness, opacity and gloss were determined for both the $V C$ and $H P$ samples. These nondestructive measurements help to characterize papers. As optical properties depend on the structure of the paper, they can be useful for comparison with other historic papers and help to create a conservation-restoration protocol.

The brightness of papers in the $V C$ is mainly distributed into two groups, one in a range between 40 and $50 \%$ (41 papers) and the other in a range between 50 and $60 \%$ (37 papers). Most $V C$ papers have a degree of yellowness in a range between 20 and $30 \%$. The measured opacity values are very high, between 90 and $100 \%$. Very low gloss values, below 2.5 , tell us that the papers are uncoated. The most representative gloss values for $V C$ papers are between 1 and 1.5, occurring in $77 \%$ of cases (Fig. 6).

The brightness values of six samples of historical papers were in a range between 40 and 66\% (Fig. 7). For other samples, values below $40 \%$ were obtained, the lowest being $18,2 \%$ for an $H P$ sample from the sixteenth century. Seven samples showed yellowness values between 20 and $40 \%$, and three (from the 16th and 16 -seventeenth centuries) were darker, with yellowness values over $45 \%$. Very high opacity values, over $90 \%$, were seen in $H P$ samples, with a further subgrouping as follows: three samples were in a range between 90 and 95\%, and the remainder in a range between 95 and $100 \%$. The measured gloss values on $H P$ were

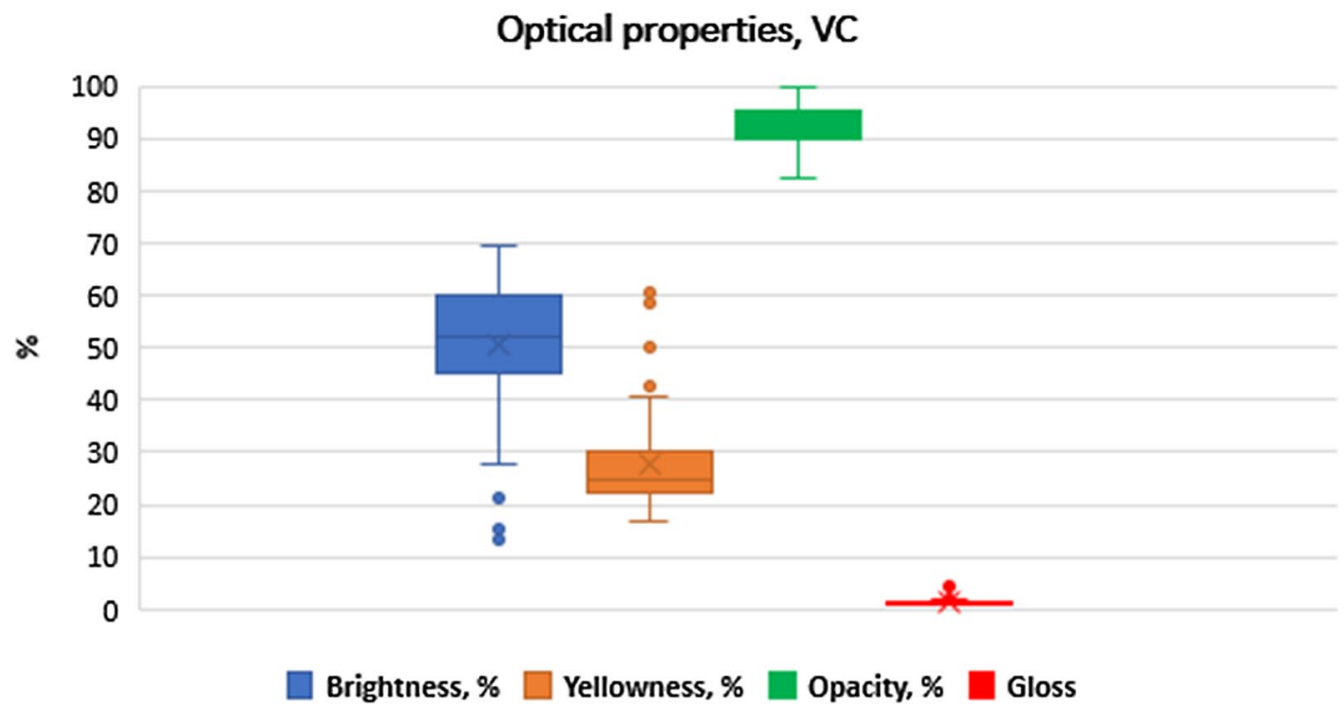

Fig. 6 Optical properties of the VC papers 


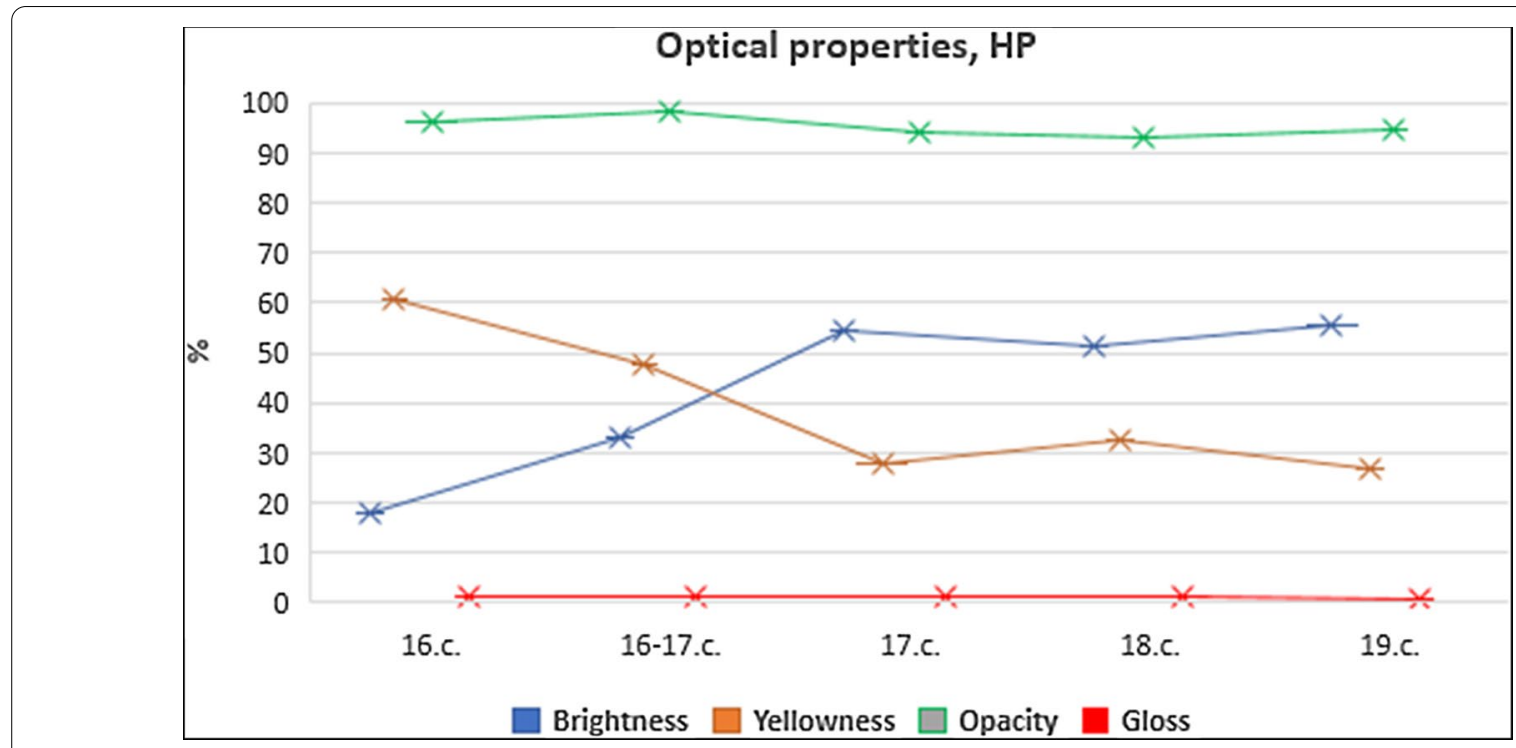

Fig. 7 Optical properties of HP samples

approximately 1 . The exception were papers from the nineteenth century (sample 2D) with a measured gloss value of 0.73 .

The measurements of optical properties of the $V C$ and $H P$ samples revealed low brightness, high yellowness, very high opacity and extremely low gloss. Among the optical properties, ANOVA test proved significant difference in gloss $(p=0.0001)$ and opacity $(p=0.0152)$, whereas brightness $(p=0.3268)$ and yellowness $(\mathrm{p}=0.1365)$ showed no significant difference in values between the $V C$ and $H P$ samples.

The Pearson correlation coefficient was determined along with the optical properties, thickness, $\mathrm{pH}$ content and water absorption of $H P$ samples (Fig. 8). A negligible correlation was obtained between optical properties, water absorption and thickness, with the exception of

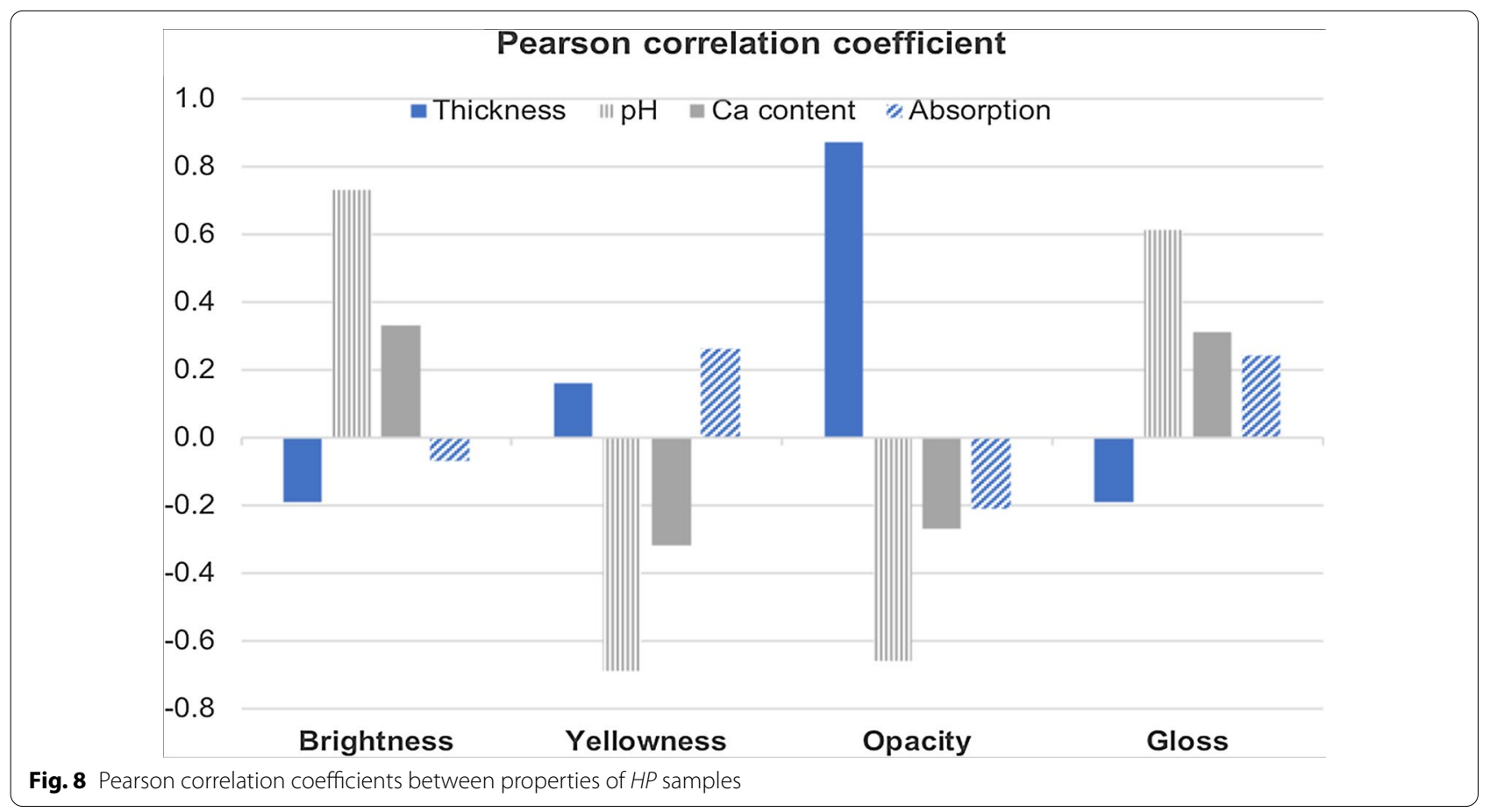


opacity, for which the positive correlation was high $(r=0.87)$. A weak linear relationship between the calcium content in papers and their optical properties was observed. With increasing amounts of calcium in the paper, the brightness and gloss increase as well, while yellowness and opacity decrease. A strong linear relationship between all optical properties and paper $\mathrm{pH}$ values was observed $(\mathrm{r}> \pm 0.6)$. Papers with higher $\mathrm{pH}$ values have higher brightness and gloss and lower yellowness and opacity. Also, a positive linear correlation $(\mathrm{r}=0.71)$ between the amount of calcium in the paper and its $\mathrm{pH}$ value was obtained.

Multiple regression analysis was used to determine whether there is a statistically significant relationship between individual properties and how two independent properties, namely thickness and $\mathrm{pH}$ value, influence the optical properties of $H P$ samples. The results are summarized in Table 6. A multiple regression coefficient shows a strong relationship between the properties. On the other hand, $R^{2}$ and adjusted $R^{2}$ show an acceptable predicted outcome only for opacity. A p-value below 0.05 for brightness and opacity means that a significant relationship exists between thickness and $\mathrm{pH}$ value, whereas no significant correlation was obtained for yellowness and gloss. The p-values for each independent property show a highly significant relationship between thickness and opacity $(\mathrm{p}=0.009)$. The $\mathrm{pH}$ value showed a significant relationship with brightness $(\mathrm{p}=0.015)$ and yellowness $(\mathrm{p}=0.025)$ and marginal significance with gloss $(\mathrm{p}=0.08)$.

\section{Spot tests}

The water absorption test is a micro-destructive method, as shown by the residual line spots formed after the measurement (Fig. 9). For this reason, the test was applied only on $H P$ samples. Papers showed different behaviours regarding water absorption.

Thus, the least absorbent samples were $5 \mathrm{D}$ and $6 \mathrm{D}$, which took between 6 and $7 \mathrm{~min}$ to absorb a drop of water, followed by samples 3D, 4D, 9D, and 10D which took approximately $3 \mathrm{~min}$ to absorb a drop of water. This process took approximately $2 \mathrm{~min}$ for samples 7D and 8D, while in samples $1 \mathrm{D}$ and $2 \mathrm{D}$ it took less than half a minute. The absorbency of paper depends on its structure and surface properties of the paper and it is primarily determined by the sizing. Comparing differences in the paper absorbency with the structure of the paper surface on SEM micrographs, a connection between them could be seen. The differences between samples 1D and 5D are evident in the absorbency and sizing.

A test to prove the presence of starch was carried out to determine whether the paper samples contained starch that was used for sizing in the production of handmade papers.

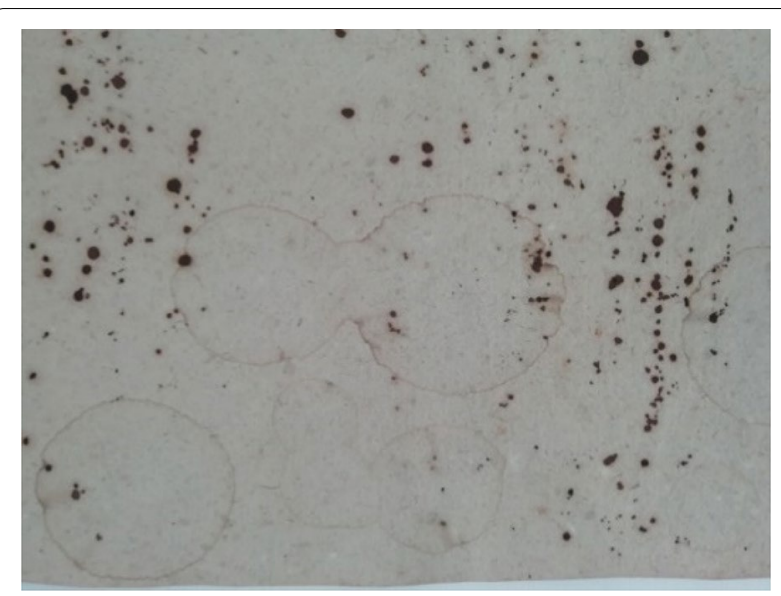

Fig. 9 Line stains formed after measurement on sample 2D

In all ten tested HP samples (Fig. 10), none matched the expected results for the presence of starch [48].

The aim of determining the presence of lignin in papers from the sixteenth-nineteenth century was to obtain indications if papers included fibres with more lignin. The test is primarily designed to determine the presence of wood fibres in paper, as wood contains a high proportion of lignin [48].

If the paper has a small amount of lignin-containing fibres, the individual fibres turn red and can be seen with the naked eye [47]. The spot test for determining lignin with phloroglucinol (Fig. 10) showed the presence of fibres containing lignin in most $H P$ samples. If we obtain 2-3 lignin fibres on a $1 \mathrm{~cm}^{2}$ paper sample, this is evidence for a lignin content of less than $<5 \%$. Ten tested samples showed four categories of results regarding the amount of stained fibres in the paper. In only one sample, namely 10D (sixteenth century), no stained fibres were found, whereas in two samples- 2D (nineteenth century) and 6D (eighteenth century) there were larger numbers of stained fibres (lignin content $>5 \%)$. Two samples, 4D (16-seventeenth century) and 7D (nineteenth century), contained a moderate amount of stained fibres, and five samples (lignin content $\approx 5 \%$ ), namely $1 \mathrm{D}$ (seventeenth century), 3D (16-seventeenth century), 5D (eighteenth century), 8D (nineteenth century), and 9D (16-seventeenth century), contained small numbers of stained fibres (lignin content $<5 \%$ ). It can be concluded that all papers but one contain stained fibres and that a majority of samples contain a small number of stained fibres.

\section{Microscopic and spectroscopic analyses SEM-EDS}

SEM-EDS analysis was applied to characterize the surface structure of paper and to identify fibres and 


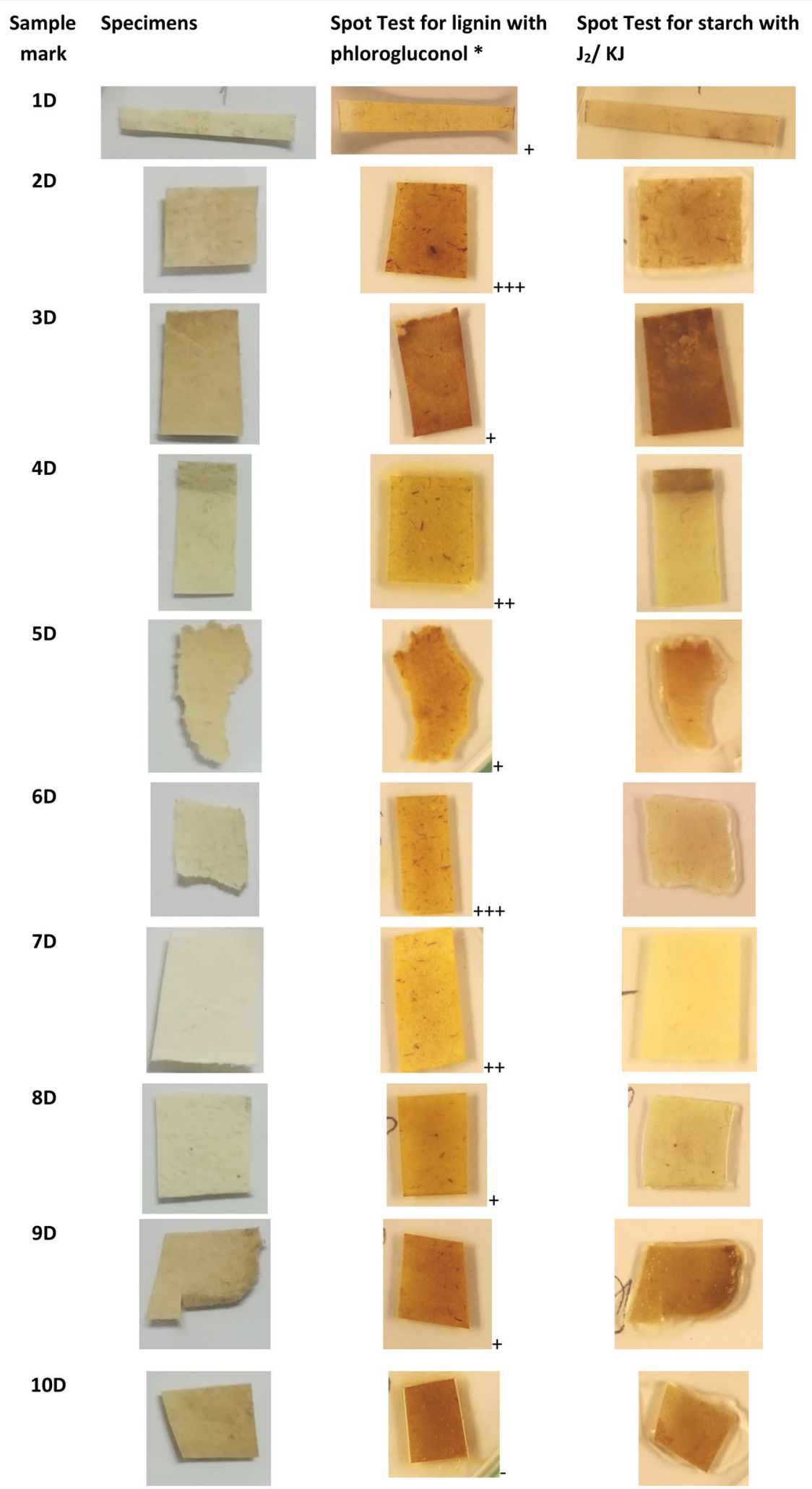

* display of the amount of stained fibres: -No stained fibres, + small amount of stained fibres $(<5 \%),++$ moderate amount of stained fibres $(\approx 5 \%),+++$ higher amount of stained fibres $(>5 \%)$

Fig. 10 Results of the spot tests for lignin and starch in HP 
elemental composition. Because this method is destructive, only the second set of samples, the $H P$, were examined. SEM images of the paper surface and spectra with elements found in the recorded location are presented in Additional file 1.

According to the EDS results, in most samples $\mathrm{O}$ (oxygen), $\mathrm{C}$ (carbon) and $\mathrm{Ca}$ (calcium) were detected, except in samples 3D, 4D and 9D, in which Ca was not observed. $\mathrm{Si}$ (silicon), $\mathrm{Cu}$ (copper), $\mathrm{Al}$ (aluminium) and $\mathrm{Ni}$ (nickel) were detected in most samples as trace elements. $\mathrm{Mg}$ (magnesium) was also visible in trace quantities in samples 7D, 8D, 9D and 10D, while S (sulphur), Ag (silver), and $\mathrm{Au}$ (gold) appear in only one sample (4D), which may represent contamination.

The SEM micrographs show differences between the samples. In some samples (1D and 5D) the spaces between the fibres are filled (Fig. 11b), indicating that surface sizing was applied, while the others had less filled spaces between the fibres (Fig. 11a). In other samples (1D and 10D), a larger number of unidentified particles are visible on the surface of the fibres.

\section{$X R F$}

XRF analysis (Additional file 1) was used to characterize the composition of $H P$ samples and to complement the results obtained by the SEM-EDS analysis. In all samples, calcium $(\mathrm{Ca})$ was present, with the highest concentration/content determined in samples 5D, 6D and 8D, followed by samples $1 \mathrm{D}$ and 10D. In four samples (2D, 3D, 9D and 10D), iron (Fe) was also detected in addition to calcium. Trace amounts of silicon $(\mathrm{Si})$, manganese $(\mathrm{Mn})$, and sulphur (S) were observed in all samples, potassium (K) was observed in seven samples, while aluminium (Al) was observed only in samples 3D and 4D.
In the SEM-EDS and XRF analyses, many elements have been recorded that can be related to the composition of the paper. Thus, sulphur (S), potassium (K), and, in some samples iron (Fe) were observed in the XRF spectra, while aluminium $(\mathrm{Al})$ and copper $(\mathrm{Cu})$ were observed in the SEM-EDS spectra. Sulphur is part of the molecular structure of gypsum $\left(\mathrm{CaSO}_{4} \times \mathrm{H}_{2} \mathrm{O}\right)$ and alum $\left(\mathrm{KAl}\left(\mathrm{SO}_{4}\right)_{2} \times 12 \mathrm{H}_{2} \mathrm{O}\right)$; aluminium $(\mathrm{Al})$ and potassium $(\mathrm{K})$ are also present. Iron $(\mathrm{Fe})$ was observed in trace quantities in all XRF spectra and can be attributed to the composition of iron alum $\left(\mathrm{FeAl}\left(\mathrm{SO}_{4}\right)_{2} \times 12 \mathrm{H}_{2} \mathrm{O}\right)$. Silicon (Si) was detected in both elemental analyses. According to the literature, it is associated with the presence of straw. Straw stalks contain silicon oxide $\left(\mathrm{SiO}_{2}\right)$ at $4-7 \%$ for wheat straw $[29,44]$. The presence of most of the elements recorded in trace quantities during elemental analyses could be explained, while some of them, such as manganese $(\mathrm{Mn})$, magnesium $(\mathrm{Mg})$, titanium $(\mathrm{Ti})$, copper $(\mathrm{Cu})$ and nickel $(\mathrm{Ni})$, should be attributed to sample contamination.

\section{FTIR-ATR}

FTIR spectroscopy, a simple technique for rapidly obtaining information about the chemical structure and crystallinity of cellulose samples, is often used in research of historical papers. We used this technique to record ATRFTIR spectra on HP samples. According to the literature on the composition of historical papers, the expected components are cellulose fibres, including straw fibres [47], gelatine, gypsum, and calcium carbonate [18, 41, 49]. The raw materials used in papermaking in Europe until the nineteenth century were rags from used textiles (flax, hemp, cotton). The reference spectra of cellulose fibres have very similar absorption bands in the wavenumber
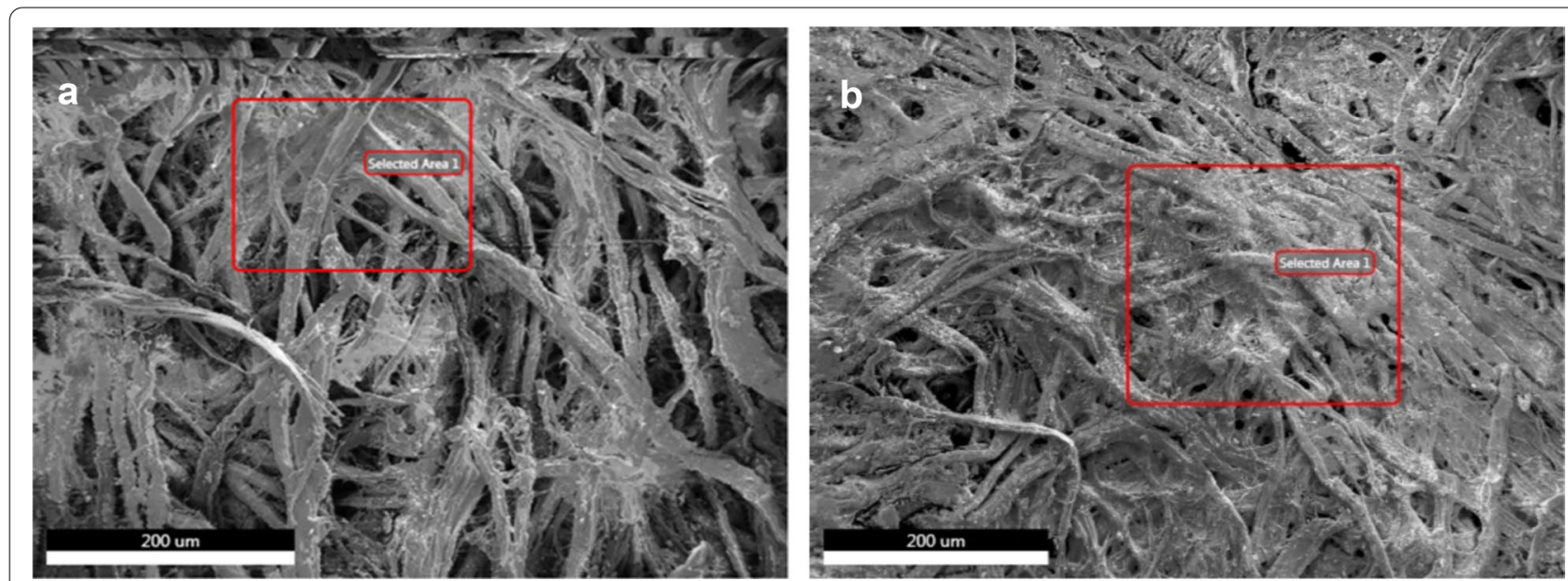

Fig. 11 SEM micrographs a sample 1D, the spaces between the fibres are less filled (sixteenth-seventeenth century); b sample 5D, spaces between fibres are filled (eighteenth century) 
range of $3660-2900 \mathrm{~cm}^{-1}$ (the stretching vibrations of $\mathrm{OH}$ and $\mathrm{CH}$ bonds in polysaccharides), while the band at $3331 \mathrm{~cm}^{-1}$ is characteristic of the stretching vibration of $\mathrm{OH}$ groups [50]. Typical bands assigned to cellulose in the range of $1630-900 \mathrm{~cm}^{-1}$, according to [50-52], are as follows:

- Band at $1633 \mathrm{~cm}^{-1}$ corresponds to the vibration of water absorbed in cellulose,

- Band at $1430 \mathrm{~cm}^{-1}$ corresponds to $\mathrm{CH}_{2}$ vibrations, $\mathrm{HCH}$ and $\mathrm{OCH}$ in-plane bending

- Band at $1367 \mathrm{~cm}^{-1}$ corresponds to $\mathrm{COH}$ and $\mathrm{HCC}$ vibrations,

- Band at $1335 \mathrm{~cm}^{-1}$ corresponds to $\mathrm{OH}$ and $\mathrm{CH}_{2}$ vibrations,

- Band at $1155 \mathrm{~cm}^{-1}$ corresponds to COC asymmetric vibration,

- Band at $1110 \mathrm{~cm}^{-1}$ corresponds to the asymmetric vibration of a glycosidic ring,

- Band at $895 \mathrm{~cm}^{-1}$ corresponds to COC vibrations of glycoside bonds.

By examining the spectra of the individual samples and comparing them with the reference spectra, it can be noted that cellulose has two dominant regions: one is in the fingerprint region with a sharp band at $1029 \mathrm{~cm}^{-1}$ with two smaller bands at approximately $1050 \mathrm{~cm}^{-1}$ and $1100 \mathrm{~cm}^{-1}$, and the second region is in the area of stretching single bonds at approximately $3600-3000 \mathrm{~cm}^{-1}$. Thus, HP samples showed characteristic FTIR spectral features of cellulose [51, 52]. Furthermore, in most samples absorption bands at 2900 and $2849 \mathrm{~cm}^{-1}$, attributed to $\mathrm{CH}$ stretching vibrations of cellulose and symmetric $\mathrm{CH}_{2}$ stretching vibrations of non-cellulose polysaccharides were observed as peaks or as shoulders. The absorption band at $2918 \mathrm{~cm}^{-1}$ attributed to asymmetric $\mathrm{CH}_{2}$ stretching vibrations in non-cellulose polysaccharides was present as a sharp band in samples 5D, 6D, 7D, 8D, 9D and 10D, whereas, in four other samples, it was present as a shoulder (Fig. 12). This triplet is indicative of flax fibres [53]. In the study of Kostadinovska et al. [18], eight patterns were proposed to determine the prevailing type and quantity of fibres in the sample. By comparing the spectra of $H P$ samples with the proposed patterns in all samples, the flax fibres were confirmed as the dominant component. In samples 2D and 3D, in addition to flax, a larger amount of hemp was identified, whereas, in sample 4D, a larger amount of cotton was present. Sample 1D showing absorption bands at 2902, 1506, 1031, 1000

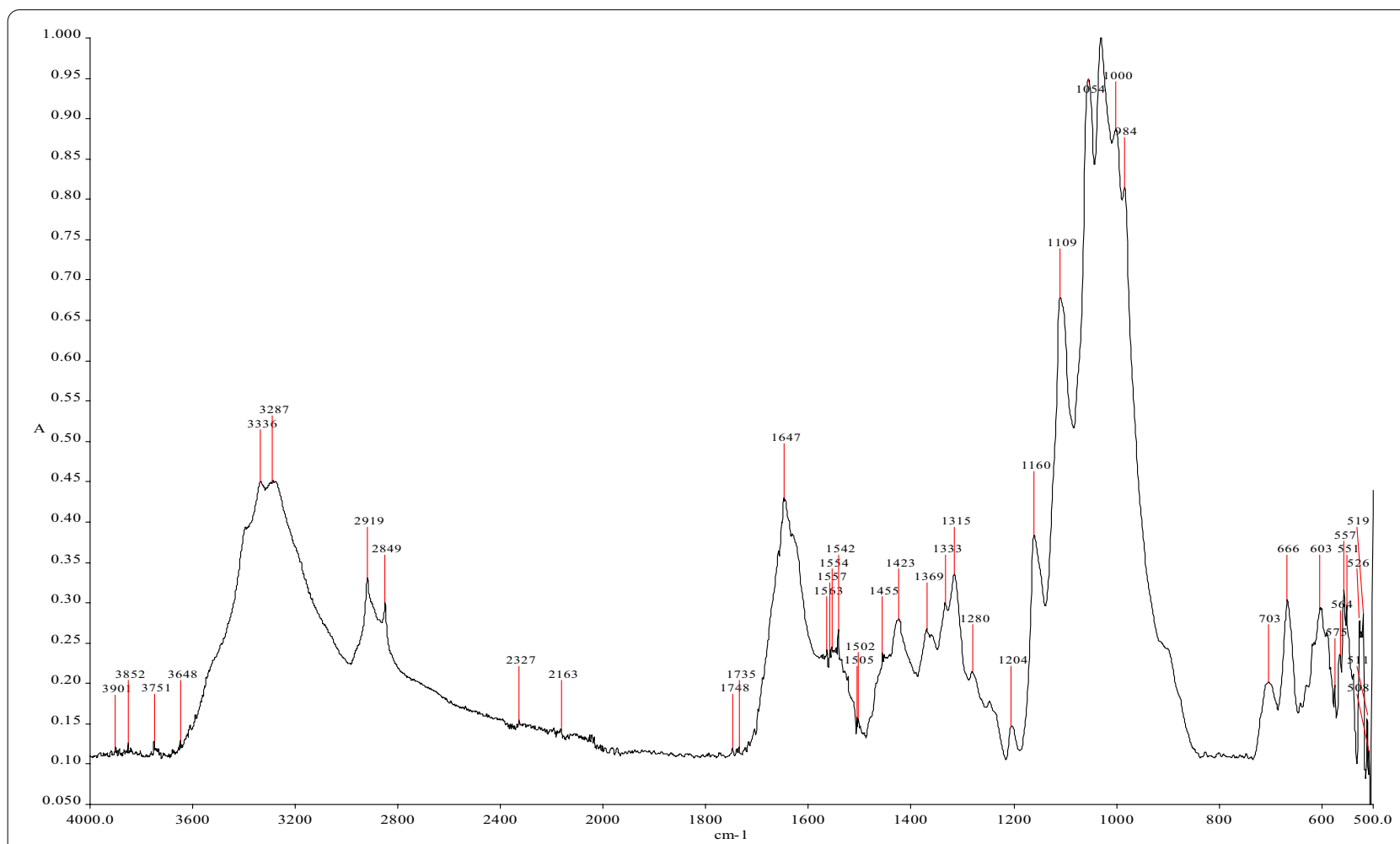

Fig. 12 ATR-FTIR spectrum of 9D sample 


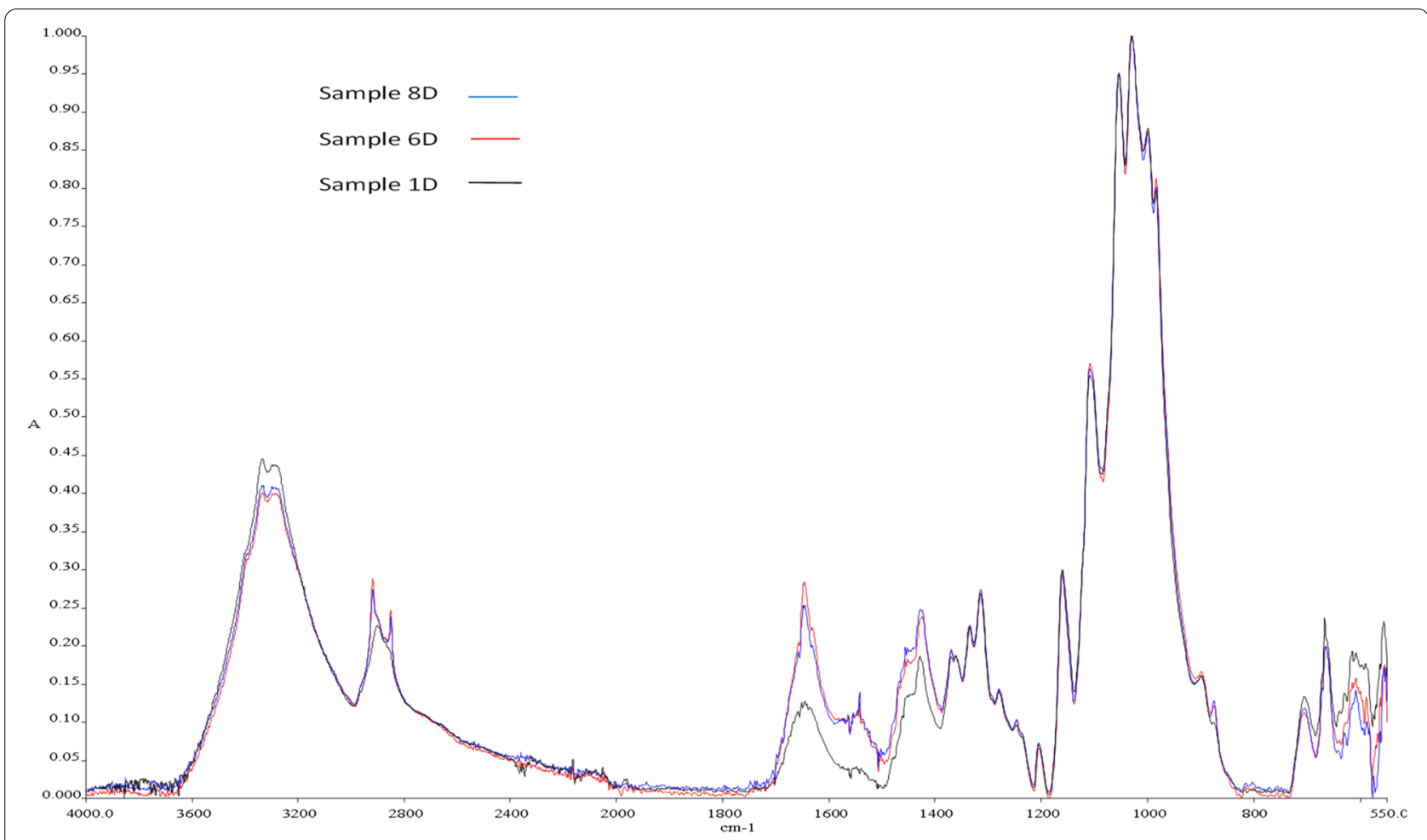

Fig. 13 ATR-FTIR spectra of historic papers sorted by dates: 1D (seventeenth century), 6D (eighteenth century) and 8D (nineteenth century)

and $898 \mathrm{~cm}^{-1}$ and shoulders at 2900 and $2851 \mathrm{~cm}^{-1}$ suggested that, in addition to flax fibres, hemp prevailed over cotton (Fig. 13). A weak absorption band at $1735 \mathrm{~cm}^{-1}$ present in all $H P$ samples is characteristic of the $\mathrm{C}=\mathrm{O}$ ester band in pectins, confirming the presence of hemp, although it could also show the presence of carbonyl groups of oxycelluloses found in degraded materials [51].

The absence of an absorption band at $1595 \mathrm{~cm}^{-1}$ and a very weak absorption band at $1505 \mathrm{~cm}^{-1}$, which are characteristic bands for lignin, confirm that all examined papers were made from pulped rags. The lignin content was too low for FTIR in reflectance mode to detect it.

The spectra of additives (sizing agents and fillers) in paper, such as gelatine, starch, calcium carbonate and gypsum, overlap with the spectra of cellulose in the fingerprint region, so it is difficult to confirm with certainty the presence of individual materials. The absorption bands related to proteins below $1400 \mathrm{~cm}^{-1}$ could be assigned to amide III, those in the region of 100 to $1500 \mathrm{~cm}^{-1}$ to amides I and II, and bands over $3000 \mathrm{~cm}^{-1}$ (characteristic for $\mathrm{NH}$ and $\mathrm{CH}$ stretching) to amides $\mathrm{A}$ and $B$ [54]. For papers sized with animal gelatine, the absorption bands at approximately $1645 / 1650 \mathrm{~cm}^{-1}$, associated with the $\mathrm{C}=\mathrm{O}$ stretching vibration, and $1545 / 1550 \mathrm{~cm}^{-1}$, associated with the $\mathrm{NH}$ in-plane bending vibration, were observed in the spectra. In all $H P$ samples, doublets at 1648 and $1645 \mathrm{~cm}^{-1}$ and weak absorption bands at $1550 / 1548 \mathrm{~cm}^{-1}$ were found, which could indicate the presence of gelatine in the papers (Fig. 12).

Calcium carbonate shows a strong absorption band in the fingerprint region at approximately $1425 \mathrm{~cm}^{-1}$ and two weaker absorption bands at 875 and $712 \mathrm{~cm}^{-1}$ [55]. The presence of an absorption band at $1425 \mathrm{~cm}^{-1}$ in all $H P$ samples, in addition to indicating the presence of calcium carbonate, is assigned to $\mathrm{CH}_{2}$ and $\mathrm{CH}$ vibrations in cellulose. The differences among samples were observed in the other two bands. The absorption band at $875 \mathrm{~cm}^{-1}$ was clearly observed in samples $5 \mathrm{D}, 6 \mathrm{D}$ and $8 \mathrm{D}$ and present as small peaks in samples 1D, 3D, 4D, 7D and 10D. In samples 2D and 9D, it was only a shoulder. A very weak absorption band at $711 \mathrm{~cm}^{-1}$ was observed in samples 5D and $6 \mathrm{D}$ and as a shoulder in samples 3D, 7D, 8D and 10D. Calcium in historic papers could be present in the form of calcium stearate, which shows an absorption peak at $2851 \mathrm{~cm}^{-1}$ and carboxylate bands at 1577 and $1541 \mathrm{~cm}^{-1}$ [12]. Both absorption bands (1575 and $1542 \mathrm{~cm}^{-1}$ ) were present in all the samples, except in $2 \mathrm{D}$, where only a band at $1542 \mathrm{~cm}^{-1}$ was observed.

Gypsum has two dominant sharp bands, one in the fingerprint region and the other in the region of asymmetric 
and symmetric $\mathrm{OH}$ single stretching bands, at $3394 \mathrm{~cm}^{-1}$. The other two bands typical for gypsum are at 667 and $595 \mathrm{~cm}^{-1}$ [56]. In both regions, the bands overlap with the cellulose bands, making them difficult to identify. Nevertheless, we identified a band at $3394 \mathrm{~cm}^{-1}$ present as a shoulder in all the samples and in samples 9D and $10 \mathrm{D}$ as a small peak. The absorption band at approximately $660 \mathrm{~cm}^{-1}\left(\mathrm{SO}_{4}{ }^{2-}\right.$ bending) overlaps with the $\mathrm{OH}$ out-of-plane bending vibration in cellulose and was detected at $667 \mathrm{~cm}^{-1}$ in all HP samples. The absorption band at $595 \mathrm{~cm}^{-1}$ was present as a small intensity peak in most samples and as a shoulder in samples 2D, 5D, 7D and 9D.

By comparing all recorded ATR-FTIR spectra, we conclude that there is a very small difference between the samples. As pulped rags were used for paper production, the presence of flax, hemp and cotton fibres in the samples is expected, flax being the prevailing fibre component in most samples. In samples 1D, 2D and 3D, a larger amount of hemp was identified, while sample 4D contained cotton. In Fig. 13, the ART-FTIR spectra of three samples $(1 \mathrm{D}, 6 \mathrm{D}$, and $8 \mathrm{D})$ from the seventeenth, eighteenth and nineteenth centuries are shown. The peaks mostly overlap, though in some parts of the spectrum they are different, which indicates the difference in the share of additives in the paper samples from the 17th to the nineteenth centuries. We can assume that gelatine was used for sizing in all cases. The presence of calcium compounds in the form of carbonate, sulphate or stearate could be predicted in all HP samples, albeit in different forms and quantities. Although the number of examined samples is small (10 samples), it is evident that there is a difference in the proportion of additives, which corresponds to previous research [9]. Namely, over time the amounts of additives (sizing and fillers) in the paper changes, which affects the durability and stability of the paper.

\section{Conclusions}

The papers of the Valvasor's collection $(V C)$ are of unknown origin and composition. We aimed to collect documentation and define characteristics of these papers for potential use by future researchers in the field of handmade paper or by conservators-restorers. Due to the fact that the $V C$ papers could not be subject to destruction, only non-destructive analyses were performed on them, but we used another set of 10 samples of historical papers $(H P)$ to extend the research to destructive / micro-destructive analyses. By comparing the results of the performed analyses, a connection was explored by which it was possible to define some characteristics of the $V C$ paper. With this study, we aimed to provide a model approach for other researchers who seek to document the characteristics of paper in their collections. Measurement results were processed by statistical tools. The Pearson correlation coefficient determined the correlation between optical properties, thickness, calcium content, $\mathrm{pH}$, and absorbency. Multiple regression analysis determined the relationship between optical properties, thickness and $\mathrm{pH}$. Connection of $\mathrm{pH}$ with brightness and yellowness was proven significant, as well as that of $\mathrm{pH}$ with gloss, though in a lesser degree. Relationship between thickness and opacity has also proved significant. This led us to presume possible characteristics of the $V C$ paper, without subjecting these heritage papers to destructive or micro-destructive analyses. Morphological analysis of the fibres showed that most of the fibres in the HP samples were flax and hemp, while FTIR analysis confirmed a higher proportion of flax fibres and hemp along with cotton. Microscopic analyses of the paper surface showed the same type of specific fibres in the $V C$ and $H P$ samples. Both sets of samples feature thin light brown fibres $(<150 \mu \mathrm{m})$ along with blue and red ones. These thin fibres resemble straw. A spot test for lignin on $H P$ samples showed that they contained fibres with a certain amount of lignin, which may also indicate straw. This can be confirmed by the results of SEM-EDS and XRF, where Si (silicon) possibly originating from silica in the straw is present in traces. In our view, SEM-EDS, XRF and ATR-FTIR analyses performed on HP samples proved valuable in presuming the composition of $V C$ papers. The optical properties of paper were proven to be related to calcium content and $\mathrm{pH}$ values. The higher the calcium content, the higher the $\mathrm{pH}$ and the brightness of papers. The results of SEM-EDS, XRF, and FTIR analyses showed that a small proportion of calcium in HP samples affects their optical properties. From this we infer that the VC papers do not have high calcium content. Although the differences between values of optical properties, $\mathrm{pH}$, and calcium content are small, they are nevertheless visible and confirmed with the statistical evaluation.

Although it would have been far-fetched to presume that we could determine the origin of the $V C$ papers, we nevertheless obtained sufficient ground to deduce their possible composition and create a database. The $V C$ paper database constructed as part of this project, named Valper, will be presented separately.

\section{Abbreviations}

ATR-FTIR: Attenuated total reflection-Fourier transform infrared spectroscopy; HP: Historical paper samples; SEM-EDS: Scanning electron microscopy with energy dispersive spectroscopy; VC: Papers from Valvasor's collection; XRF: X-ray fluorescence analysis. 


\section{Supplementary Information}

The online version contains supplementary material available at https://doi. org/10.1186/s40494-021-00507-2.

Additional file 1. Results of SEM-EDS and XRF analysis.

\section{Acknowledgements}

The authors are grateful for the help of Damir Doračić in SEM-EDS analysis, Domagoj Mudronja in XRF analysis and Milivoj Vodopija for the copyediting. Special thanks to the Archdiocese of Zagreb for allowing the non-destructive research of the books of the Metropolitan Library.

\section{Authors' contributions}

AD designed the work, and made most of the measurements. DGS processed FTIR and made statistical evaluation of data. BL helped with the interpretation. JVT substantively revised the manuscript and designed the work. AD drafted the manuscript, DGS, JVT and BL helped to review and edit the manuscript. All authors read and approved the final manuscript.

\section{Funding}

This study was co-funded by the Slovenian Research Agency (Program P2-0213 and Infrastructural Center RIC UL-NTF).

\section{Availability of data and materials}

All data generated or analysed during this study are included in this published article and its additional files.

\section{Declarations}

\section{Competing interests}

The authors declare that they have no competing interests.

\section{Author details}

1 Central Laboratory for Conservation and Restoration, Croatian State Archives, Zagreb, Croatia. ${ }^{2}$ Faculty of Natural Sciences and Engineering, Chair of Information and Graphic Arts Technology, University of Ljubljana, Ljubljana, Slovenia. ${ }^{3}$ Restoration and Conservation Centre, Archives of the Republic of Slovenia, Ljubljana, Slovenia. ${ }^{4}$ Faculty of Graphic Arts, Chair of Materials in Graphic Technology, University of Zagreb, Zagreb, Croatia.

\section{Received: 30 September 2020 Accepted: 10 March 2021} Published online: 19 March 2021

\section{References}

1. Reisp B. Kranjski polihistor Janez Vajkard Valvasor. Ljubljana: Mladinska knjiga; 1983.

2. Budin B. The library of Janez Vajkard Valvasor. Knjižnica. 2003;47(4):99-112.

3. Hunter D. Papermaking: the history and technique of an ancient craft. New York: Dover Publications; 1978.

4. Novak G. Grafični materijali. Ljubljana: Univerza v Ljubljani Naravoslovnotehniška fakulteta; 2004

5. Rosenfeld H. Buchpreis, Antiquariatspreis und Einbandpreis im 16. und 17. Jahrhundert. Gutenberg Jahrbuch. 1958; 33.

6. Vodopivec Tomažič J, Avguštin Florjanovič B, Cjuha M, Grkman S, Harauer D, Kotar M, Petelin N, Planinc L, Rahovsky Šuligoj T, Gregor Svetec D, Kavkler K. Slava vojvodine Kranjske 1689 materialna podoba in konservatorsko-restavratorski poseg na 3. delu; Studia Valvasoriana. Zbornik spremnih študij ob prvem integralnem prevodu Die Ehre Deß Hertzogthums Crain v slovenski jezik, Zavod Dežela Kranjska. 2014; 131-173.

7. Vodopivec Tomažič J. Valvasor's Glory of the Duchy of Carniola, 1689, Vol. III: Comparative Analysis of Binding Structure and Paper, Bookbindings Theoretical Approaches and Practical Solutions. Biblioologia. 2017; 45: 227-250.

8. Biermann CJ. Handbook of pulping and papermaking. 2nd ed. London: Academic Press; 1996
9. Barrow WJ. Permanence/durability of the book-VII physical and chemical properties of book papers, 1507-1949. Richmond: W. J. Barrow Research Laboratory Inc; 1974.

10. Barrett T, Ormsby M, Lang JB. Non-Destructive Analysis of 14th-19th Century European Handmade Papers. Restaurator. 2016;37(2):93-135.

11. Mahgoub H, Bardon T, Lichtblau D, Fearn T, Strlič M. Material properties of Islamic paper. Herit Sci. 2016:4:34

12. Gorassini A, Calvini P, Baldin A. Fourier transform infrared spectroscopy (FTIR) analysis of historic paper documents as a preliminary step for chemometrical analysis. Italy: CMA4CH 2nd Mediterraneum meeting on multivariate analysis and chemometry for cultural heritage and environment. 2008; 2: 47-8.

13. Calvini P, Gorassini A. FTIR - Deconvolution Spectra of Paper Documents. Restaurator. 2002;23(1):48-66.

14. Librando V, Minniti Z. Ancient and modern paper characterization by FTIR and micro-Raman spectroscopy. Conservation Science in Cultural Heritage journal. 2011;11:249-68.

15. Trafela T, Strlič M, Kolar J, Lichtblau D, Anders M, Mencigar D, Pihlar B. Non-destructive analysis and dating of historical paper based on ir spectroscopy and chemometric data evaluation. Anal Chem. 2007;79(16):6319-23.

16. Lichtblau D, Strlič M, Trafela T, Kolar J, Anders M. Determination of mechanical properties of historical paper based on NIR spectroscopy and chemometrics - a new instrument. Appl Phys A. 2008;92(1):191-5.

17. Ganzerla R, Gambaro A, Cappelletto E, Fantin M, Montalbani S, Orland M. Characterization of selected paper documents from the archives of Palazzo Ducale (Venice), Italy using various analytical techniques. Microchem J. 2009;91:70-7.

18. Kostadinovska, M, Jakovleska-Spirovska Z, Taylor T. A procedure for identifying cellulose fibers in paper artifacts differentiating between flax, hemp and cotton. In: The 4th International Virtual Conference on Advanced Scientific Results, June, 6. - 10. 201., Zilina : Publishing Institution of the University of Zilina. 2016; 156-162.

19. Hubbe MA, Gill RA. Fillers for papermaking: a review of their properties, usage practices, and their mechanistic role. BioRes. 2016;11(1):2886-963.

20. Blaznik B, Gregor-Svetec D, Bracko S. Influence of light and temperature on optical properties of papers. Cellulose Chem Technol. 2017:51(7-8):755-64

21. Kolar J, Kolesa D, De Bruin G, Sustar V. Characterisation of historical paper-possibilities and limitations. ICOM-CC Graphic Documents Working Group Interim Meeting, Vienna. 2013;17-19:42-4.

22. Brown N, Coppola F, Modelli A, Amicucci F, Lichtblau D, Strlič M. Nondestructive collection survey of the historical Classense Library. Part I: Paper characterisation. Heritage Sci. 2020;88:8.

23. Coppola F, Brown N, Amicucci F, Strlič M, Modelli A. Non-destructive collection survey of the historical Classense Library. Part II: Conservation scenarios. Heritage Sci. 2020;89:8

24. Strlič M, Liu Y, Lichtblau DA, De Bruin G, Knight B, Winther T, Kralj Cigić I, Brereton RG. Development and mining of a database of historic European paper properties. Cellulose. 2020;27:8287-99.

25. Lahanier Ch, Preusser FD, Van Zelst L. Study and conservation of museum objects: use of classical analytical techniques. Nucl Instrum Methods Phys Res. 1986:14(1):1-9.

26. Rizzutto MA, Curado JF, Bernardes S, Campos PH, Kajiya EAM, Silva TF, Rodrigues CL, Moro M, Tabacniks M, Adde N. Analytical techniques applied to study culturalheritage objects. International Nuclear Atlantic Conference-INAC 2015, São Paulo, SP, Brazil, October 4-9: 2015.

27. Kostadinovska M, Grupče O, Jakovleska Spirovska Z, Minčeva-Šukarova B. Micro-chemical and spectroscopic study of component materials in 18th and 19th century sacred books. Restaurator. 2017;38(3):299-330.

28. Kostadinovska M. Characterisation of drawing papers for Borko Lazeski's cartoons (1951-56). Restaurator. 2018;39(3):157-83.

29. Carl DM. Random Sampling: a Tool for Library Research. Coll Res Libr. 1969:30(2):119-25.

30. TAPPI T 401 os-74, Fiber analysis of paper and paperboard. 1975

31. Ilvessalo-Pfäffli M. Fiber atlas: identification of papermaking fibers. Germany: Springer-Verlag; 1995.

32. Cook JG. Handbook of textile fibres, natural fibres. 1st ed. New York: Woodhead Publishing; 1984.

33. ISO 534:2005, Paper and board - Determination of thickness, density and specific volume. 2005. 
34. TAPPI/ANSI T 529 om-1, Surface pH measurement of paper. 2014.

35. ISO 2470:1999, Paper, board and pulps-Measurement of diffuse blue reflectance factor (ISO brightness). 1999.

36. ISO 2471:1998, Paper and board-Determination of opacity (paper backing) - Diffuse reflectance method. 1998.

37. ISO 8254-1:2009, Paper and board-Measurement of specular glossPart 1: 75 degree gloss with a converging beam, TAPPI method. 2009.

38. TAPPI standard T492 pm-76, Water Absorption of Paperboard (Non-Bibulous). 1976.

39. TAPPI standard T419, Starch in paper. 1970

40. ISO 9184-3, Paper, board and pulps_Fibre furnish analysis_-Part 3: Herzberg staining test. 1990.

41. IRUG The Infrared and Raman Users Group, IRUG spectral database. 2000. http://www.irug.org/. Accessed 30 March 2020

42. International Association of Paper Historians. International Standard for the Registration of Papers with or Without Watermarks Version 2.1.1; 2013.

43. The Bernstein Consortium. The Memory of the Paper, Paper Database. 2006. https://www.memoryofpaper.eu/BernsteinPortal/appl_start.disp. Accessed 25 March 2020.

44. Eineder $\mathrm{G}$. The ancient paper-mills of the former Austro-Hungarian Empire and their watermarks. Hilversum: Paper Publications Society; 1960.

45. Ganzer G. Andrea Galvani: 1797-1855, cultura e industria nell'Ottocento a Pordenone, a cura di. Studio Tesi: Pordenone; 1994.

46. Van Velzen S T J. The universe between felt and wire. A new look into the typology of Western made paper. University of Amsterdam. UvA-DARE (Digital Academic Repository); 2018.

47. Zou X, Uesaka T, Gumagul N. Prediction of paper permanence by accelerated aging I. Kinetic analysis of the aging process. Cellulose. 1996;3:243-67.

48. Browning, B L. Analysis of Paper, 1st and 2nd eds. New York: Marcel Dekker, Inc., 1969/1977.
49. Librando V, Minniti Z. Characterization of writing materials of books of great historical-artistic Value by FT-IR and micro-Raman spectroscopy. Conserv Sci Cult Heritage J. 2014;14:39-50.

50. Hospodarova V, Singovszka E, Stevulova N. Characterization of cellulosic fibers by FTIR spectroscopy for their further implementation to building material. Am J Anal Chem. 2018;9:303-10.

51. Garside P, Wyeth P. Identification of cellulosic fibres by FTIR spectroscopy I: Thread and single sibre analysis by attenuated total reflectance. Stud Conserv. 2003;48(4):269-75.

52. Kavkler K, Demšar A. Application of FTIR and Raman spectroscopy to qualitative analysis of structural changes in cellulosic fibres. Tekstilec. 2012;55(1):19-31.

53. He J, Tang Y, Wang S-Y. Differences in morphological characteristics of bamboo fibres and other natural cellulose fibres: studies on X-ray diffraction, solid state 13C-CP/MAS NMR, and second derivative FTIR spectroscopy data. Iran Polym J. 2007;16(12):807-18.

54. Cséfalvayová L, Pelikan M, Kralj Cigić I, Kolar J, Strlič M. Use of genetic algorithms with multivariate regression for determination of gelatine in historic papers based on FT-IR and NIR spectral data. Talanta. 2010:82:1784-90.

55. Pavithra R, Gunasekaran S, Sailatha E, Kamatchi S. Investigations on paper making raw materials and determination of paper quality by FTIR-UATR and UV-Vis DRS spectroscopy. Int J Cur Res Acad Rev. 2015;3(11):42-59.

56. Liu Y, Wang A, Freeman J. J. Raman, MIR, and NIR spectroscopic study of calcium sulfates: gypsum, bassanite, and anhydrite. In: 40th Lunar and Planetary Science Conference. March 23-27. 2009; The Woodlands, Texas, id.2128.

\section{Publisher's Note}

Springer Nature remains neutral with regard to jurisdictional claims in published maps and institutional affiliations.

\section{Submit your manuscript to a SpringerOpen ${ }^{\circ}$ journal and benefit from:}

- Convenient online submission

- Rigorous peer review

- Open access: articles freely available online

- High visibility within the field

- Retaining the copyright to your article

Submit your next manuscript at $\boldsymbol{\nabla}$ springeropen.com 